\title{
Magma sources involved in the 2002 Nyiragongo eruption, as inferred from an InSAR analysis
}

\author{
C. Wauthier, ${ }^{1,2}$ V. Cayol, ${ }^{3}$ F. Kervyn, ${ }^{1}$ and N. d'Oreye ${ }^{4,5}$ \\ Received 25 January 2011; revised 12 March 2012; accepted 1 April 2012; published 17 May 2012.
}

[1] On 17 January 2002, Nyiragongo volcano erupted along a $20 \mathrm{~km}$-long fracture network extending from the volcano to the city of Goma. The event was captured by InSAR data from the ERS-2 and RADARSAT-1 satellites. A combination of 3D numerical modeling and inversions is used to analyze these displacements. Using Akaike Information Criteria, we determine that a model with two subvertical dikes is the most likely explanation for the 2002 InSAR deformation signal. A first, shallow dike, $2 \mathrm{~km}$ high, is associated with the eruptive fissure, and a second, deeper dike, $6 \mathrm{~km}$ high and $40 \mathrm{~km}$ long, lies about $3 \mathrm{~km}$ below the city of Goma. As the deep dike extends laterally for $20 \mathrm{~km}$ beneath the gas-rich Lake Kivu, the interaction of magma and dissolved gas should be considered as a significant hazard for future eruptions. A likely scenario for the eruption is that the magma supply to a deep reservoir started ten months before the eruption, as indicated by LP events and tremor. Stress analysis indicates that the deep dike could have triggered the injection of magma from the lake and shallow reservoir into the eruptive dike. The deep dike induced the opening of the southern part of this shallow dike, to which it transmitted magma though a narrow dike. This model is consistent with the geochemical analysis, the lava rheology and the pre- and post-eruptive seismicity. We infer low overpressures (1-10 MPa) for the dikes. These values are consistent with lithostatic crustal stresses close to the dikes and low magma pressure. As a consequence, the dike direction is probably not controlled by stresses but rather by a reduced tensile strength, inherited from previous rift intrusions. The lithostatic stresses indicate that magmatic activity is intense enough to relax tensional stresses associated with the rift extension.

Citation: Wauthier, C., V. Cayol, F. Kervyn, and N. d'Oreye (2012), Magma sources involved in the 2002 Nyiragongo eruption, as inferred from an InSAR analysis, J. Geophys. Res., 117, B05411, doi:10.1029/2011JB008257.

\section{Introduction}

[2] On 17 January 2002, Nyiragongo volcano, located in the eastern Democratic Republic of Congo (DRC), erupted along a system of fractures extending from the volcano to the city of Goma, $15 \mathrm{~km}$ south of the volcano. Two lava flows entered the town and forced 350,000 out of a total of 400,000 inhabitants to evacuate. About $15 \%$ of the city was destroyed. The number of reported casualties was limited to

\footnotetext{
${ }^{1}$ Earth Sciences Department, Royal Museum for Central Africa, Tervuren, Belgium.

${ }^{2}$ GeMMe Unit - Georesources and Geo-Imaging, University of Liege, Liège, Belgium.

${ }^{3}$ Laboratory Magmas et Volcans, Université Blaise Pascal, UMR 6524, OPGC, Clermont-Ferrand, France.

${ }^{4}$ Department of Geophysics/Astrophysics, National Museum of Natural History, Luxembourg, Luxembourg.

${ }^{5}$ European Center for Geodynamics and Seismology, Walferdange, Luxembourg.

Corresponding author: C. Wauthier, GeMMe Unit - Georesources and Geo-Imaging, University of Liege, 1 Chemin des Chevreuils, Bldg. B52, B-4000 Liège, Belgium. (c.wauthier@gmail.com)

Copyright 2012 by the American Geophysical Union. 0148-0227/12/2011JB008257
}

about 100, despite the large amount of damage to infrastructure, due to the eruption starting in the morning.

[3] The region around Nyiragongo is threatened by various hazards. First, Nyiragongo lava is known to be very fluid and able to produce rapid flows that can reach $100 \mathrm{~km} / \mathrm{h}$ [Tazieff, 1977]. These lavas were responsible for casualties during the 1977 eruption of Nyiragongo volcano. Second, eruptive fractures can reach Lake Kivu and produce phreatomagmatic lacustrine eruptions. This is shown by the presence of numerous volcanic cones on the lake floor [Capart, 1955], as well as hydro-magmatic tuff cones on the northern shore [Denaeyer, 1963; Capaccioni et al., 2002/2003], such as Mont Goma (C. G. Newhall and M. L. Tuttle, Volcanic, earthquake, and lake gas hazards of the Lake Kivu and Virunga Mountains area, Rwanda-Zaire-Uganda, administrative report for USAID/OFDA, unpublished report, 1988). Moreover, Lake Kivu contains layers with large amounts of dissolved carbon dioxide and methane. A magma eruption into the lake could disturb this stratification, lead to gas exsolution and cause a major regional disaster [Schmid et al., 2005]. Finally, volcanic and rift-related tectonic earthquakes can damage urban areas. As these hazards could affect the one million people leaving on the northern side of Lake Kivu, 


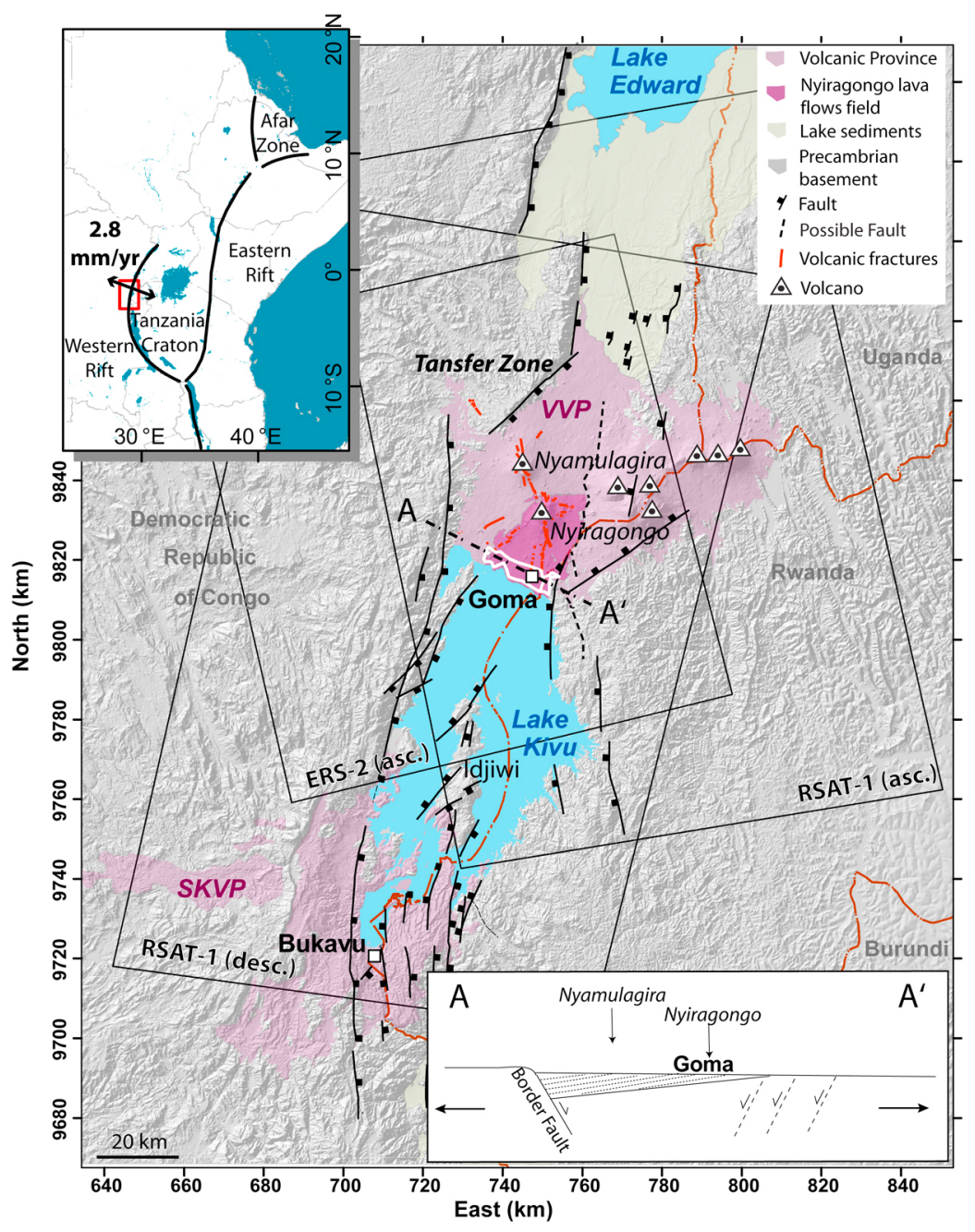

Figure 1. Shaded relief topographic map of North Kivu indicating the locations of the Nyiragongo, Nyamulagira and other Virunga volcanoes. The original frames of interferograms calculated in this study (Table 1) are indicated by black rectangles. Lower-right inset shows a schematic profile along $\mathrm{AA}^{\prime}$. The rift extension direction in this area is about $\mathrm{N} 110^{\circ} \mathrm{E}$ [Stamps et al., 2008]. The Goma-Gisenyi urban area is circled in white. The rift extension in the Kivu area is derived from Stamps et al. [2008]. SKVP and VVP stand for South Kivu Volcanic and Virunga Volcanic Province, respectively. Main rift-related normal faults are from Villeneuve [1980].

mainly in the contiguous cities of Goma (RDC) and Gisenyi (Rwanda), the region is at very high natural risk. Thus an understanding of the processes involved in the 2002 Nyiragongo eruption is essential for assessing the overall hazards.

[4] Due to poor security conditions and the lack of local funding, the only ground-based data available are restricted to measurements of the level of Lake Kivu performed shortly after the eruption, and repeated a few months later. The fact that only two seismic stations were operating at the time of the eruption meant that the recorded earthquakes could not be accurately located, nor could there be a thorough analysis of the seismicity. However, Interferometric Synthetic Aperture Radar (InSAR) captured surface deformation associated with the eruption along three different beams. One was supplied by the ERS-2 satellite along ascending orbits, and two were supplied by the RADARSAT-1 satellite along ascending and descending orbits. Since few quantitative ground-based observations are available, the
InSAR data are very valuable for gaining a better understanding of the magmatic and tectonic processes involved in the eruption.

[5] The main objectives of this study are: (1) to make an accurate assessment of the volcanic hazards; (2) to define the location and geometry of the magma sources involved in the January 2002 eruption; (3) to understand the mechanical interactions between these sources, and the chronology of the eruption; (4) to determine the stress state in the lithosphere and gain a better understanding of rifting processes in this part of the EAR.

\section{Background}

\subsection{Geologic Setting}

[6] Nyiragongo volcano (Figure 1) lies on the East African Rift (EAR). The $3000 \mathrm{~km}-$ long EAR has propagated from north to south, as shown by systematic variations 


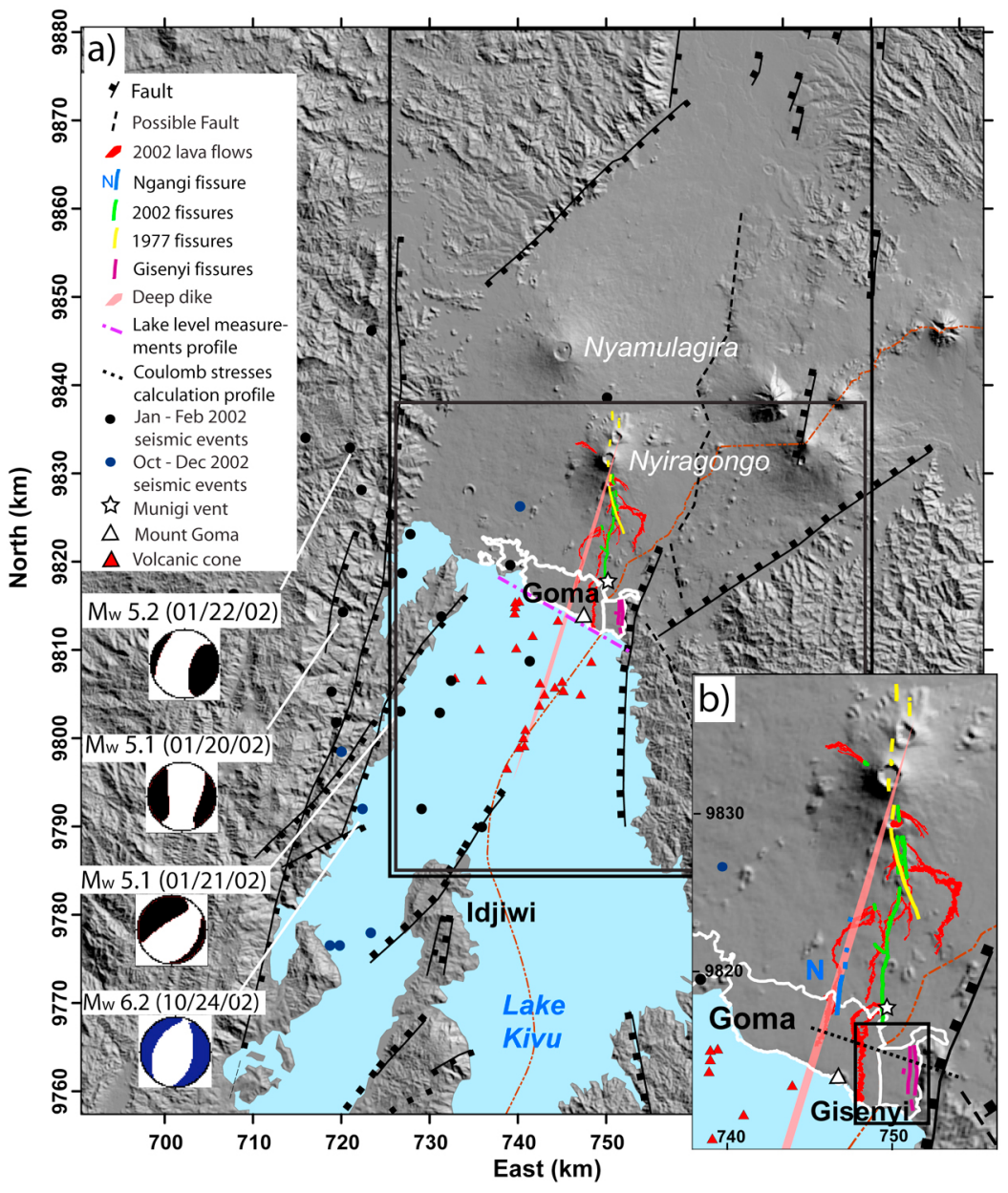

Figure 2. (a) Shaded relief topographic map of the Goma area and Lake Kivu. The main volcanic cones on the floor of lake Kivu are from Capart [1955] and Schmid et al. [2010]. Lake level changes (Figure 3) were measured on the northern shore of Lake Kivu along the direction indicated with a bold purple dashed line. The large black rectangle shows the extent of Figure 4. The small black rectangle shows the area where InSAR displacements have been quantitatively used to determine the best fit model (Figure 9). (b) Inset shows the Goma and Gisenyi urban areas highlighted in white, the location of Ngangi fissures, Munigi and the Coulomb stresses calculation profile (Figure 10). The black rectangle indicates the location of Figures 5a and 5b. The 2002 Nyiragongo eruptive fissures, as well as the Ngangi fissures were mapped from a $2.5 \mathrm{~m}$ resolution Spot image from 2009 and from a $1 \mathrm{~m}$ resolution Ikonos image from 2008. The 2002 fissure on the northern flank of the volcano were determined from the northernmost lava flow location. The 1977 eruptive fissures were mapped from field observations.

in geophysical, geochemical and geomorphological data [Chorowicz, 2005]. Spreading rates decrease from $6.5 \mathrm{~mm} /$ year in the north of the rift to $1.5 \mathrm{~mm} /$ year in the south of the rift [Stamps et al., 2008]. In the Virunga Volcanic Province (VVP), where the rift trend is NNE, with localized NE trends, the spreading rate has an intermediate value of $2.8 \mathrm{~cm}$. The rift in the VVP is most probably a half-graben with a marked normal fault on the western side and no clear normal bounding fault on the eastern side (Figure 1) [Ebinger, 1989a].

[7] Nyiragongo and Nyamulagira volcanoes, $\sim 15 \mathrm{~km}$ apart, are the youngest and most westerly volcanoes of the VVP (Figure 1). Distribution of cones and eruptive fissures at Nyamulagira and Nyiragongo generally follows the NE rift trend, but there is also a NNW-trending fracture network (Figure 1), which may be due to the stress field generated by the interplay between the magmatic systems of both volcanoes [Gudmundsson and Andrew, 2007] or to the reactivation of Precambrian basement faults [Smets et al., 2010b]. Nyamulagira and Nyiragongo volcanoes are located at the intersection between these two trends. The location of the volcanic centers with respect to the Kivu border faults indicates interaction between the volcanism and faulting [Ebinger, 1989b].

[8] While Nyamulagira erupts every 2-4 years [Smets et al., 2010a], only two historical eruptions of Nyiragongo have been recorded; in 1977 [Tazieff, 1977] and in 2002 [Komorowski et al., 2002/2003; Tedesco et al., 2007]. Nyiragongo is one of the few volcanoes on Earth to host an active lava lake. In both eruptions, the summit lava lake drained and fracture networks opened on the southern flank of the volcano (Figure 2). 


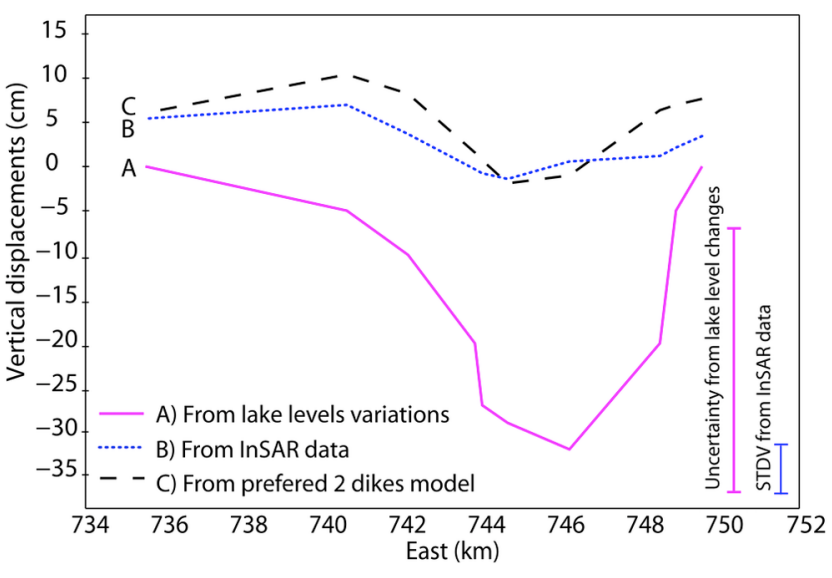

Figure 3. Vertical displacements along the northern coast of Lake Kivu (see Figure 2a for the profile location). The bold magenta line (curve A) indicates the measured lake level variations for 17 January 2002 [Tedesco et al., 2007], for which the uncertainty is estimated to be about $\pm 15 \mathrm{~cm}$ (section 2.4). The dotted blue line (curve B) indicates vertical displacements computed from the different beams using InSAR data. Standard deviation (STDV) on vertical displacements is $3.4 \mathrm{~cm}$. The dashed black line (curve C) indicates the vertical displacements from the preferred twodike model.

\subsection{Magma Reservoirs at Nyiragongo}

[9] Magma reservoirs beneath Nyiragongo are still poorly constrained. Demant et al. [1994] explain the petrography of the lavas based on two reservoirs, located at different depths, and periodically connected. The shallow reservoir, where the final fractional crystallization occurs, is assumed to be permanently connected to the active lava lake. Estimates of the shallow reservoir depth, from leucite crystallization pressures, place it at a depth varying from $4 \mathrm{~km}$ [Platz et al., 2004] to less than $1 \mathrm{~km}$ [Louaradi, 1994]. The depth of the deep reservoir, where the initial crystallization occurs, is estimated at $10-14 \mathrm{~km}$, based on petrographical analysis of fluid and melt inclusions in olivine and clinopyroxene phenocrysts [Demant et al., 1994]. This location is consistent with seismic studies which attribute the a-seismic region, which lies between the surface and a depth of 10-14 km, to a magma complex [Tanaka, 1983]. The existence of at least two magma reservoirs is confirmed by a seismic study by Shuler and Ekström [2009], which showed that a series of five unusual earthquakes of moderate size recorded during the 2002 eruption could be attributed to the successive collapse of the roofs of the two connected magma reservoirs.

\subsection{The January 2002 Nyiragongo Eruption}

[10] On 17 January 2002, Nyiragongo erupted along a $20 \mathrm{~km}$-long fracture network extending southward from the northwestern flank of the volcano, toward the airport and city of Goma. Part of the 1977 fracture network was reactivated (Figure 2). A small radial fissure opened on the northwestern flank of the volcano, while a $12 \mathrm{~km}$-long N-S fracture system opened on the southern flank, almost parallel to the main rift-related faults (Figure 2). The observed opening is about $1-3 \mathrm{~m}$. The eruption lasted for 12 [Tedesco et al., 2007] to $48 \mathrm{~h}$ [Komorowski et al., 2002/2003]. The erupted volume is estimated to be in the order of 14-34 $\times$ $10^{6} \mathrm{~m}^{3}$ [Tedesco et al., 2007].

\subsection{Available in Situ Data}

[11] Field surveys, conducted after the eruption, provided lava samples from different parts of the eruptive fracture system. Based on ${ }^{238} \mathrm{U}$ and ${ }^{232} \mathrm{Th}$ series radioactive disequilibria data, Tedesco et al. [2007] inferred that up to three different magma sources were involved in the eruption. The northern vents emitted degassed lava drained from the lava lake, possibly combined with input from a shallow magmatic reservoir located below the main Nyiragongo edifice. The southern part of the eruptive fissure, which opened at the end of the eruption, released gas-rich lavas as indicated by the lava fountains. This observation, together with the disequilibria analysis, indicates that this magma originated from a deeper source, probably located beneath the city of Goma.

[12] After the eruption, carbon dioxide and methane emanations were observed around the eruptive fissures and in several locations in Goma between 300 and $800 \mathrm{~m}$ from the lava flows [Komorowski et al., 2002/2003]. Methane bursts were also reported in Goma, south of Munigi (Figure 2) during the eruption [Komorowski et al., 2002/2003]. This methane could be stored in pockets [Tedesco et al., 2007] located within the sediments filling the Lake Kivu basin and might be released continuously via tectonic fractures throughout the whole region [Komorowski et al., 2002/2003]. The sudden fracturing associated with the 2002 eruption could have triggered the degassing.

[13] The two operating seismic stations showed that precursory seismicity started ten months before the eruption [Kavotha et al., 2002/2003]. It was characterized by the onset of continuous volcanic tremor, and an increased number of long-period and short-period earthquakes, sometimes followed by increased fumarolic activity [Tedesco et al., 2007]. Magma might thus have been supplied to a reservoir in the months preceding the eruption [Kavotha et al., 2002/2003]. Between 4 and 16 January 2002, and after the effusive activity had stopped, seismic activity remained high [Kavotha et al., 2002/2003]. About 100 tectonic earthquakes with magnitudes greater than 3.5 were recorded in the five days following the eruption over the whole Lake Kivu area [Tedesco et al., 2007], culminating in a $6.2 \mathrm{M}_{\mathrm{w}}$ event on 24 October, 2002 [Mavonga, 2007]. Although the seismic network was not capable of accurately determining the location of the seismic events, they generally cluster along the faults on the western side of the Kivu basin, as found for previous recorded events [Zana and Hamaguchi, 1978; Mavonga, 2007]. The Harvard Centroid Moment Tensor (CMT) focal mechanisms for the three largest January 2002 earthquakes $\left(>5 \mathrm{M}_{\mathrm{w}}\right)$ indicate almost pure normal faulting mechanisms.

[14] Building damage was reported during the two weeks after the eruption, especially in Gisenyi (Figure $2 b$ ) [Komorowski et al., 2002/2003]. During field investigations carried out in January 2010, the inhabitants of the damaged houses indicated that the initiation of the cracks was contemporaneous with the January 2002 Nyiragongo eruption. New cracks also opened up several years after the eruption, some appearing in early 2009. The Rwandese Red Cross, which has been measuring the extension of certain cracks in the Gisenyi Hospital, confirmed that crack widening is still 

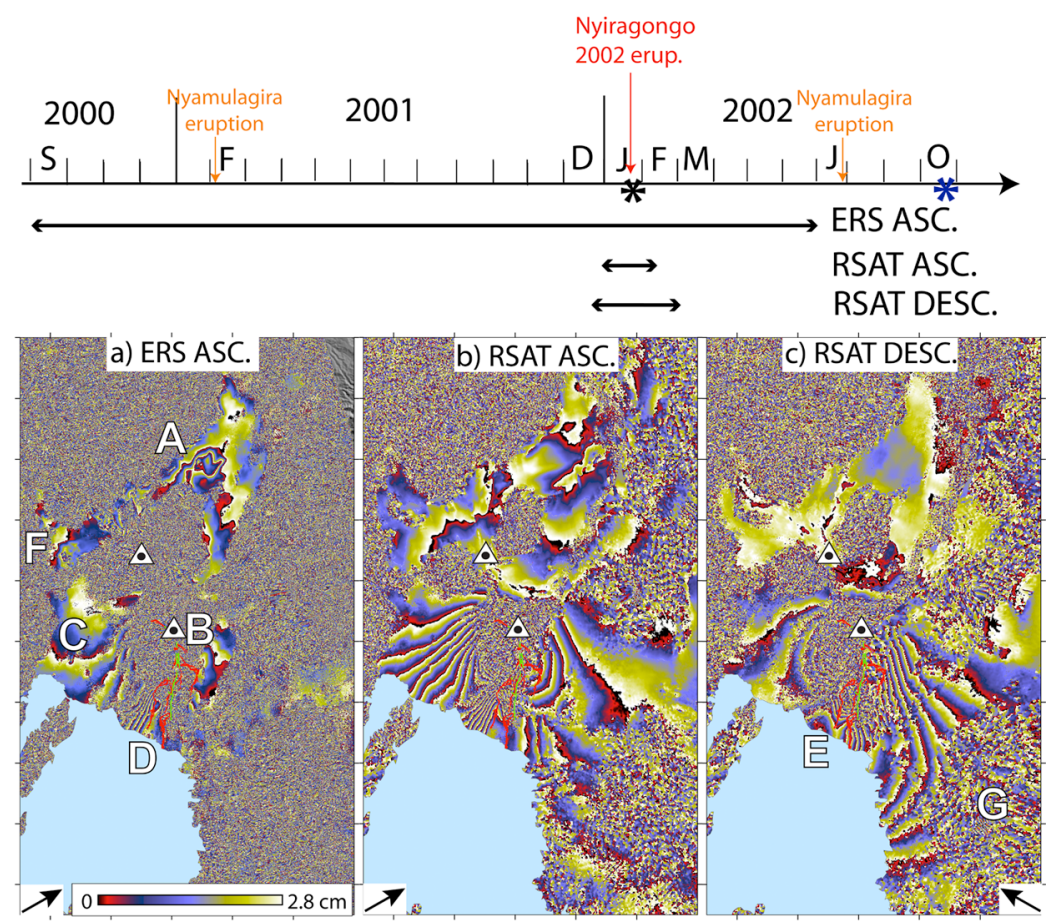

Figure 4. Three wrapped, unmasked interferograms showing the deformation associated with the 2002 Nyiragongo eruption. One color cycle represents a $2.8 \mathrm{~cm}$ Line Of Sight (LOS) range change with positive fringes (red-blue-yellow) corresponding to a range increase. The arrows show LOS direction. The 2002 lava flows are shown in red and the eruptive fissures are drawn in green. Nyiragongo and Nyamulagira volcanoes are indicated by triangles. See the text for the interpretations of signals referred to as A, B, C, D, E, F and G. Location of the area shown is indicated by a box in Figure 2a. (a) ERS-2 ascending interferogram, (b) ascending RADARSAT-1 interferogram and (c) descending RADARSAT-1 interferogram. The earthquakes for which we do have the CMT focal mechanisms (Figure 2a) are indicated by stars on the time line.

ongoing. In some cases, vertical movement was noted, with the western side moving down.

[15] After the eruption, local inhabitants reported a noticeable rise in the water level of the lake along the shoreline in the Goma area. Eleven days after the eruption, water level changes were estimated by measuring the depth of the immerged algae zone $(\sim 30 \mathrm{~cm}$ thick) that develops just below the water surface (J. Durieux, personal communication, 2005). These measurements were repeated at irregular intervals until March 2002 [Komorowski et al., 2002/2003; Tedesco et al., 2007] and showed an asymmetric increase in the water level of Lake Kivu, which reached a maximum of about $37 \mathrm{~cm}$ at the Goma shore (Profile A in Figure 3). Due to the agitation of the water surface by waves, and given possible additional sources of perturbations such as water discharge at the $100 \mathrm{~km}$-distant Ruzizi hydroelectric dam, seasonal effects, seiches, etc., uncertainties can conservatively be estimated to be of the order of $30 \mathrm{~cm}$. This water level change has been attributed [Komorowski et al., 2002/ 2003] to subsidence of the rift system around Goma as the asymmetry is consistent with the asymmetry of the graben in which the VVP is located [Ebinger, 1989a].

\section{Processing of InSAR Data and First-Order Observations}

[16] InSAR data provide high spatial resolution measurements of surface deformation with centimeter to sub- centimeter accuracy [Massonnet and Feigl, 1998]. Nowadays InSAR is widely used to study a broad range of volcanic and seismic events [e.g., Bürgmann et al., 2000; Wright et al., 2006; Yun et al., 2006, and references therein].

[17] The January 2002 eruptive event was captured by C-band SAR sensors (wavelength of $5.6 \mathrm{~cm}$ ) on board satellites ERS-2 and RADARSAT-1 in different beams. No descending ERS-2 interferograms were suitable for modeling. We use the most coherent available ERS-2 ascending interferogram, spanning 665 days, as well as one ascending and one descending RADARSAT-1 interferogram spanning 48 and 72 days, respectively. Temporal decorrelation is due to the change of scattering properties within a pixel. It is lower in the short time span RADARSAT-1 interferograms than in the long time span ERS-2 interferogram (Figure 4 and Table 1). As shown by previous studies of the Kivu area [Poland, 2006; Colclough, 2005; Wauthier et al., 2009; d'Oreye et al., 2008] and confirmed by this study, the dense tropical vegetation induces major temporal decorrelation. In C-band interferograms with long time spans, coherence is only preserved on lava flows. Furthermore, the steep, upper flanks of Nyiragongo are affected by geometrical decorrelation [Hanssen, 2001]. Finally, the surface of Lake Kivu does not allow the phase to be preserved, and prevents us from getting any information on ground deformation beneath the lake's surface.

[18] We processed the interferograms with the Jet Propulsion Laboratory/Caltech repeat orbit interferometry 
Table 1. Characteristics of the Three Interferograms Used in This Study ${ }^{\mathrm{a}}$

\begin{tabular}{|c|c|c|c|c|c|c|}
\hline Satellite & $\begin{array}{c}\text { LOS vector } \\
\text { [East, North, Up] }\end{array}$ & Time Span & $h_{a}{ }^{\mathrm{b}}(\mathrm{m})$ & Frame(s) & Variance $\left(\mathrm{m}^{2}\right)$ & $\begin{array}{c}\text { Correlation } \\
\text { Distance }(\mathrm{m})\end{array}$ \\
\hline ERS-2 (asc.) & {$[-0.36,-0.08,0.93]$} & $\begin{array}{c}2000 / 09 / 06-2002 / 07 / 03 \\
\text { (665 days) }\end{array}$ & 147 & 7158 & $2.2 \times 10^{4}$ & 10843 \\
\hline RSAT-1 (asc.) & {$[-0.59,-0.13,0.80]$} & $\begin{array}{c}2001 / 12 / 31-2002 / 02 / 17 \\
\text { (48 days) }\end{array}$ & 77 & $\begin{array}{l}\text { M: } 7135 \text { and } 7150 \\
\text { S: } 7136 \text { and } 7151\end{array}$ & $4.6 \times 10^{5}$ & 9152 \\
\hline RSAT-1 (desc.) & {$[0.50,-0.11,0.86]$} & $\begin{array}{c}2001 / 12 / 21-2002 / 03 / 03 \\
\text { ( } 72 \text { days) }\end{array}$ & 119 & $\begin{array}{l}\text { M: } 3631 \text { and } 3646 \\
\text { S: } 3631 \text { and } 3647\end{array}$ & $7.1 \times 10^{5}$ & 11925 \\
\hline
\end{tabular}

\footnotetext{
${ }^{\mathrm{a}}$ The variance $\left(\sigma_{d}^{2}\right)$ and correlation length $(a)$ characterizing the random correlated noise present in each InSAR data set are determined in the undeformed areas.

${ }^{\mathrm{b}}$ The altitude of ambiguity, $h_{a}$, corresponds to the DEM error required to generate one topographic-related fringe.
}

ROI_PAC software [Rosen et al., 2004]. A 1-arc second digital elevation model (DEM) from the Shuttle Radar Topographic Mission (SRTM) [Farr et al., 2007] was used to correct for the topographic phase. Two consecutive frames were merged to form each of the RADARSAT-1 interferograms (Table 1 and Figure 4). Interferograms were filtered using power spectrum filtering, followed by an adaptive smoothing using Fast Fourier Transform [Goldstein and Werner, 1998]. Finally, we unwrapped the interferometric phases using the SNAPHU software [Chen and Zebker, 2001].

[19] Incorrect modeling of the orbital satellite trajectories results in large-scale parallel fringes that can affect interferograms. One way to remove linear orbital trends from the interferograms is to identify coherent areas unaffected by deformation, caused either by the Nyiragongo 2002 eruption or by lava flow compaction. As RADARSAT-1 orbits are poorly known, all RADARSAT-1 interferograms are affected by such orbital phase ramps (Figure S1 in the auxiliary material). ${ }^{1}$ By using short time spans (Table 1 ) and the large extent of the RADARSAT-1 scenes (Figure 1) we have successfully identified coherent undeformed areas, and thus corrected orbital trends. In contrast, the large time span ERS-2 interferogram lacks coherent undeformed areas, which makes it impossible to identify the orbital phase contributions with any accuracy. However, as we use the precise ERS-2 orbits provided by the Delft Institute of Earth Observation and Space Systems (DEOS), the orbital phase contribution is assumed to be very small.

[20] Acquisition times of the available SAR scenes [d'Oreye et al., 2008; Poland, 2006] indicate that the main observed ground deformation took place between 14 January and 13 February 2002. InSAR data show complex ground displacements, with several overlapping fringe patterns, which could be associated with a combination of sources, both magmatic and regionally tectonic in origin.

[21] The Line-Of-Sight (LOS) range increase observed in the area marked A in Figure 4a corresponds to the compaction of an accumulation of Nyamulagira lava flows from the 1958, 1967, 1980 and 1991-93 eruptions [Smets et al., 2010a]. We do not attempt to model it here, as we are focusing only on the 2002 Nyiragongo eruption.

[22] Fringes with asymmetric LOS range changes to the east and west of the eruptive fissure (B and C, Figure 4a) also correspond to opposite range changes for the descending and

\footnotetext{
${ }^{1}$ Auxiliary materials are available in the HTML. doi:10.1029/ 2011JB008257.
}
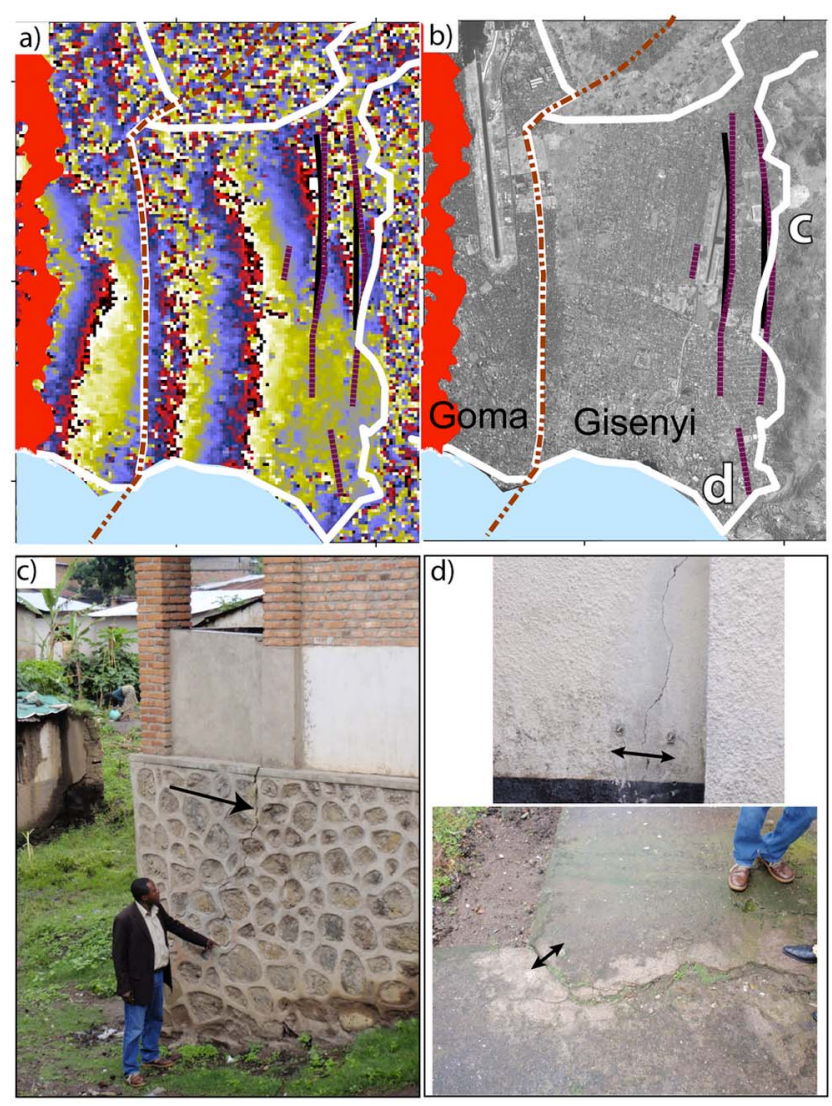

Figure 5. (a) Detail from the descending RADARSAT-1 interferogram (see Figure $2 \mathrm{~b}$ for location) which is neither multi-looked in range nor filtered in order to have the finest resolution for the identification of the discontinuities. Faults inferred from the interferogram are indicated as black lines and from cracks in buildings as dotted magenta lines. The border between RDC and Rwanda is indicated by a brown line. The city of Goma is indicated by the white circled area, and the 2002 lava flow is in red. (b) Ikonos-2 image (Panchromatic $1 \mathrm{~m}$ spatial resolution) from 11 July 2008 showing a comparison between the fault traces inferred from the RADARSAT-1 interferogram and buildings. Location of photographs (Figures 5c and 5d) are shown. (c) Photograph of a cracked house taken close to Ginsenyi airport. (d) Photographs taken in the Gisenyi hospital where regular caliper measurements are performed between two marks which indicate that the fissures are still widening. 

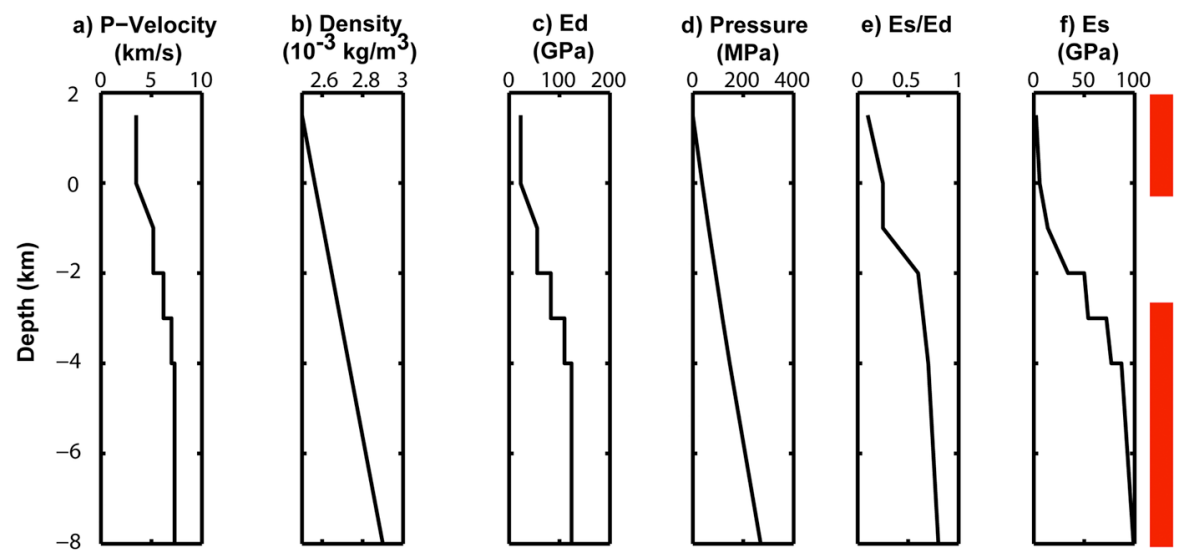

Figure 6. Estimated crustal structure in the Virunga area. (a) Estimated $\mathrm{P}$ wave velocity structure obtained in the Virunga area [Mavonga, 2010]. (b) Density structure assumed to be similar to Hawaii. (c) Inferred dynamic value of Young's modulus from equation (1). (d) Ambient lithostatic pressure computed from the presumed density structure. (e) Ratio of static to dynamic Young's modulus from laboratory measurements [Cheng and Johnston, 1981]. (f) Estimated static value of Young's modulus. The thick red line indicates the depths of dikes from the best fit model. $0 \mathrm{~km}$ corresponds to sea level.

ascending modes. Their pattern is consistent with dike intrusions and is presumably related to one or more of the dikes that fed the 2002 eruption.

[23] In the Goma area, an increase in LOS range occurs in the ascending and descending modes (D in Figure 4a), indicating subsidence, which reaches nearly 5 fringes in the ascending orbits. A range decrease of about 1.5 fringes ( $E$ in Figure 4c) is also visible to the west of the lava flows, though only in the RADARSAT-1 descending mode. The RADARSAT-1 interferogram also shows two $2.5 \mathrm{~km}$-long displacement discontinuities (Figure 5), of only 1/3 of a fringe each, in the city of Gisenyi (Rwanda). In order to retain a fine resolution this interferogram was neither multilooked in range ( 5 pixels in azimuth for 1 pixel in range) nor filtered (Figure 5).

[24] One to two fringes, indicating a range increase to the northwest of Nyamulagira volcano ( $\mathrm{F}$ in Figure $4 \mathrm{a}$ ), are visible in both the ERS-2 and RADARSAT-1 ascending beams. The signal could be associated with deformation of the nearby Nyamulagira volcano. Analyzing this volcano is beyond the scope of this study, so we do not attempt to model the signal in $\mathrm{F}$.

[25] Finally, four to five fringes with decreasing LOS range are visible in the western part of the descending RADARSAT-1 interferogram ( $G$ in Figure 4c). Such a large signal is not visible in the ascending RADARSAT-1 interferogram (Figure $4 \mathrm{~b}$ ) and this area is incoherent in the ERS2 interferogram (Figure 4a). A deep source beneath Lake Kivu is likely to be involved.

\section{Simultaneous Inversion of Source Geometry, Location and Displacement Distribution}

[26] Ground displacements are linearly related to the slip, or opening distribution, and nonlinearly to the source geometry and location. Therefore, the inversion of geodetic data associated with faulting or diking events usually follows a two-step procedure: nonlinear inversion is used to determine the fracture geometry assuming uniform dislocation on a rectangular fracture located in a half-space, followed by kinematic linear inversion to determine the slip or opening distribution on the previously determined fracture [Arnadottir et al., 1991; Amelung et al., 2000]. However, there is no reason for the fracture geometry determined for a uniform dislocation to be the same as the geometry determined for a variable dislocation distribution.

[27] Here, following Fukushima et al. [2005, 2010] for dikes and Sun et al. [2011] for faults, we determine the sources of the observed InSAR displacements by simultaneously inverting for a quadrangular fracture geometry, location and uniform stress changes on the dikes or faults, leading to non-uniform displacement distributions. The method used here [Fukushima et al., 2005] combines 3D numerical models, based on a boundary element numerical method [Cayol and Cornet, 1997], with nonlinear inversions, based on a near neighborhood algorithm [Sambridge, 1999a, 1999b].

\subsection{Mechanical Properties of the Crust}

[28] The edifice is assumed to be linearly elastic, homogeneous and isotropic. However, elastic properties vary over the rift depth and width. Although there is no data to document the lateral variation of the elastic properties, a seismic velocity profile of the Virunga area [Mavonga, 2010] showed that seismic velocities increase from $3.5 \mathrm{~km} / \mathrm{s}$ at sea level to $7.3 \mathrm{~km} / \mathrm{s}$ at $7.5 \mathrm{~km}$ b.s.l. (Figure 6a). Experimental values of Poisson's ratio, $\nu$, for basalts range from 0.22 to 0.28 for low to high confining pressure, corresponding to a depth of several $\mathrm{km}$ [Birch, 1966]. We take an average Poisson's ratio of 0.25 . The Young's modulus, density and Poisson's ratio contribute to the seismic velocities. Young's modulus can be determined from:

$$
E_{d}=V_{p}^{2} \rho_{r} \frac{(1-2 \nu)(1+\nu)}{(1-\nu)}
$$

where $V_{p}$ is $\mathrm{P}$ wave the seismic velocity, $E_{d}$ is the dynamically determined Young's modulus and $\rho_{r}$ is the rock 
density. Based on studies in Hawaii [Zucca et al., 1982], we assume that the density varies from $2500 \mathrm{~kg} / \mathrm{m}^{3}$ at shallow depth, where vesiculated lava flows are present, to $2900 \mathrm{~kg} / \mathrm{m}^{3}$ at greater depth where the rocks are compacted (Figure 6b). Density at shallow depth is consistent with the value of $2500 \mathrm{~kg} / \mathrm{m}^{3}$ estimated from a gravity survey around Nyiragongo and Nyamulagira volcanoes [Mishina, 1983]. In the absence of data we assume the density variation to be linear with depth.

[29] From seismic velocities, the dynamic Young's modulus is estimated to increase with depth from $23 \mathrm{GPa}$ to $124 \mathrm{GPa}$ (Figure 6c). Laboratory experiments [Cheng and Johnston, 1981; Adelinet et al., 2010] show that statically determined values of Young's modulus, $E_{s}$, are always less than dynamically determined values, $E_{d}$, and that the $E_{s} / E_{d}$ ratio increases with confining pressure, and decreases with porosity and crack density. Here, confining pressure is estimated by integrating the product of the density and the depth (Figure 6d).

[30] We further consider an elevated porosity and crack density close to the surface, leading to a lower ratio of $E_{s} / E_{d}$ of 0.1 which was determined by Cheng and Johnston [1981] for tuffs at very low confining pressures. The $E_{s} / E_{d}$ ratio for larger confining pressures is estimated from the study of Adelinet et al. [2010]. It is assumed to increase from $E_{s} / E_{d}=$ 0.25 at sea level to 0.8 at a confining pressure of $200 \mathrm{MPa}$ (Figure 6e). Thus, our first order estimate is that the Young's modulus varies from $2.3 \mathrm{GPa}$ close to the surface to $100 \mathrm{GPa}$ at $9.5 \mathrm{~km}$ below the surface (Figure $6 \mathrm{f}$ ).

[31] Preliminary models [Wauthier, 2007] showed that the dike associated with the 2002 eruptive fissure is shallow. As our modeling method is for a homogeneous medium, we must consider a single Young's modulus value in the computations. We take a value of $5 \mathrm{GPa}$, corresponding to the Young's modulus value in the upper two kilometers of the crust, which is the average depth of the presumed eruption dike.

\subsection{Three-Dimensional Boundary Element Modeling}

[32] The numerical modeling method is a mixed boundary element method (MBEM) [Cayol and Cornet, 1997]. Boundary element methods are used to solve linear partial differential equations that have been formulated as integral equations. Linear integral equations relating Green's function to prescribed boundary conditions are obtained and simultaneously solved for the unknown boundary conditions, so that mechanical interactions between sources are taken into account. The MBEM computes the three-dimensional displacements caused by sources such as tensile cracks, faults or reservoirs of arbitrary geometry located beneath a realistic topography. Nyiragongo volcano has steep slopes of more than 20 degrees. At Piton de la Fournaise volcano, where slopes are similar to Nyiragongo, Fukushima et al. [2005] found that neglecting the topography resulted in an overestimation of the overpressure (30\%), height (30\%) and volume $(20 \%)$ of the modeled dike intrusion.

[33] Boundaries are meshed by planar triangular elements. The topographic mesh is constructed from the DEM used for the InSAR processing and also includes a rough bathymetry [Capart, 1955; Schmid et al., 2010]. The size of the mesh is about five times greater ( $200 \mathrm{~km}$ in radius) than the deformation extent, so that the limited extension of the ground surface has only a small influence (around 5\%) on the computed displacements [Cayol, 1996]. The topographic mesh is dense close to the eruptive fissures in the Goma area where displacement gradients are greatest, and it becomes coarser further away (Figure S2 in the auxiliary material).

[34] Cayol and Cornet [1997] and Fukushima et al. [2005] showed that coarse meshing of the sources generally induces an overestimation of the amplitude of surface deformation, leading to an underestimation of source overpressure. We determine mesh intervals for the source by progressively diminishing the source mesh interval so that it no longer influences the results. A $400 \mathrm{~m}$ mesh interval is used for the dike associated with the 2002 eruptive fissure and elliptic reservoirs, while an $800 \mathrm{~m}$ mesh interval is used for the buried dike and faults.

[35] When a dike is connected to the ground surface, it's shape is assumed to be close to that of a quadrangle. The top part of the dike corresponds to a single smooth curve through the segmented eruptive fissure. The bottom part of the dike corresponds to a straight line defined by six parameters Dip, Shear, Botelv, Botlen, Twist and Botang (Figure 7a). These parameters are chosen in order to be able to restrict the model search to mechanically plausible models [Fukushima et al., 2005]. We do not consider the individual fissure segments mapped after the eruption (Figure 2b). Indeed, according to St Venant's principle [Love, 1927], they only influence displacements close to the eruptive fissure, where InSAR data are incoherent.

[36] To keep the number of parameters reasonably low for an efficient inversion, buried fractures are assumed to have a simpler quadrangular shape, with straight top and bottom sides (Figure 7b), leading to seven geometrical parameters, similar to the frequently used rectangular dislocation model of Okada [1985], which has three parameters when the top of the quadrangle is fixed and seven parameters when it is unknown.

[37] The prescribed boundary conditions are stress vectors that are assumed to correspond to perturbations of an initial state of stress. Indeed, a previous study [Zeller and Pollard, 1992] showed that boundary element solutions obtained with stress boundary conditions were physically more realistic than those obtained with displacement boundary conditions. It is assumed that there is no stress change at the ground surface, so that stress vectors are zero at the surface. Dikes are assumed to open as a response to magma overpressure, which is defined as being the difference between the magma pressure and the normal stress exerted by host rocks on the dike surface. Faults are assumed to slip as a response to drops in shear stress [Cayol and Cornet, 1997].

[38] We assume that each dike is submitted to a uniform overpressure. Since dikes are fluid-filled fractures, all parts of a dike are hydraulically connected. We further assume that the host rock stress is homogeneous close to the dike, so that the overpressure is uniform or varies linearly with depth. A depth-dependent gradient could have been assumed, but a previous study [Fukushima et al., 2005] showed that the range of acceptable gradients was so great that it could not be constrained. Moreover, we do not have a good a priori knowledge of the host rock stress, thus, of the overpressure. Using a constant stress model for dikes leads to a smoothly varying opening on the fracture [Cayol and Cornet, 1997], consistent with results obtained from linear kinematic 

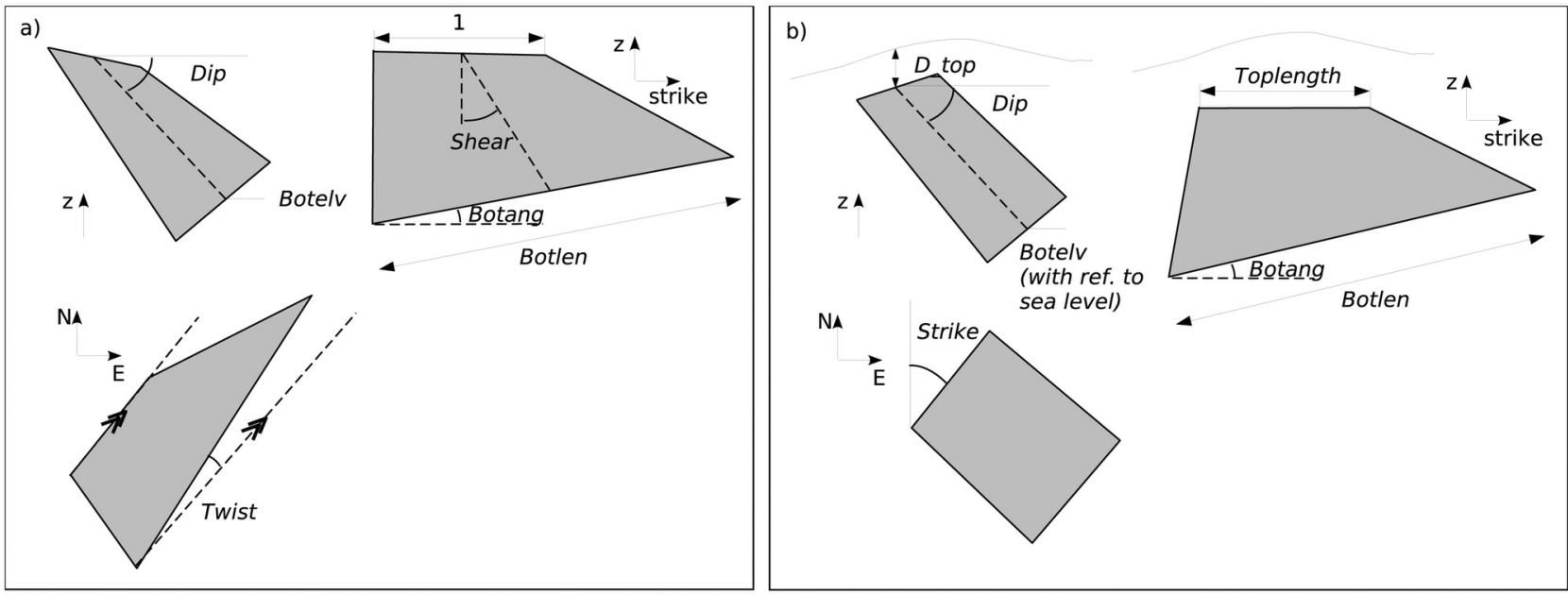

Figure 7. Geometrical parameters considered for a dike which (a) reaches and (b) does not reach the ground surface. For the dike which reaches the ground surface (Figure 7a), six parameters are used. Three parameters Dip (dip angle), Shear (angle between the dip direction and the line connecting the top and bottom line midpoints) and Botelv (elevation of the bottom line midpoint with reference to sea level) define the location of the bottom line midpoint. Three other parameters Botlen (length of the bottom scaled to that of the top), Twist (horizontal angle between the top and bottom) and Botang (vertical angle of the bottom) determine the position of the two end points of the bottom. For a buried dike (Figure $7 \mathrm{~b}$ ), seven parameters define the geometry. The top is assumed to be a straight line. Three parameters are used to define this line, Toplength, is the length, D_top is average depth below the ground surface and Strike is the angle with respect to the North direction. The same parameters as for the dike connected to the ground surface are used to define the base of the dike, with the exception of Shear and Twist that are fixed to zero to increase the inversion speed.

inversions of opening distributions [Yun et al., 2006; Pallister et al., 2010]. We invert the dike and fault geometries simultaneously with uniform stress vectors, leading to a minimum of 7 parameters per structure.

\subsection{Nonlinear Inversions}

[39] Following Fukushima et al. [2005], we use a near neighborhood inversion algorithm that consists of two stages: search and appraisal. In the search stage [Sambridge, 1999a], the model space is explored by iteratively sampling regions where data are well fitted. Multiple minima are determined. A misfit function is used which quantifies the discrepancy between observed and modeled displacements. It is written as:

$$
\chi^{2}=\left(\mathbf{u}_{\mathbf{o}}-\mathbf{u}_{\mathbf{m}}\right)^{T} \mathbf{C}_{\mathbf{d}}^{-1}\left(\mathbf{u}_{\mathbf{o}}-\mathbf{u}_{\mathbf{m}}\right)
$$

where $\mathbf{u}_{\mathbf{o}}$ and $\mathbf{u}_{\mathbf{m}}$ are vectors of observed and modeled lineof-sight (LOS) displacements, respectively, formed by concatenating data from the different beams, and $\mathbf{C}_{\mathbf{d}}$ is the data covariance matrix.

[40] To make the misfit computation numerically manageable, vectors of observed and modeled displacements $\mathbf{u}_{\mathbf{o}}$ and $\mathbf{u}_{\mathbf{m}}$ are constructed by subsampling the observed and modeled LOS displacements at the same points. Data are subsampled at circular gridded points in such a way that the subsampling is dense (the average distance between points is $800 \mathrm{~m}$ ) in areas where displacement gradients are steep, i.e., close to the 2002 eruptive fissure and in the vicinity of Goma, and coarser further away. The choice of a subsampling circular grid method was guided by the results of Fukushima et al. [2005], who showed that, for dikes, the subsampling method does not significantly affect the inversion result. Each pixel with a coherence threshold of less than 0.15 is rejected from the subsampling process (Figure S3 in the auxiliary material).

[41] The vector of observed LOS displacements is such that $\mathbf{u}_{\mathbf{o}}^{i}=\mathbf{u}_{\mathbf{o}}^{i \prime}+$ off ${ }^{i}$, where $\mathbf{u}_{\mathbf{o}}^{i \prime}$ and $\mathbf{u}_{\mathbf{o}}^{i}$ are the observed displacements of the $i$ th interferogram before and after it is shifted by the amount off ${ }^{i}$. The shift of each of the interferograms off ${ }^{i}$ is determined for each forward model calculated during a near-neighbor inversion, by minimizing the misfit (equation (2)) between observed and modeled displacements $\partial \chi^{2} / \partial o f f^{i}=0$. As it is a linear model parameter, the shift is given by:

$$
o f f^{i}=\frac{\mathbf{e}^{i T} \mathbf{C}_{\mathbf{d}}^{i^{-1}}\left(\mathbf{u}_{\mathbf{m}}^{i}-\mathbf{u}_{\mathbf{o}}^{i \prime}\right)}{\mathbf{e}^{i T} \mathbf{C}_{\mathbf{d}}^{i^{-1}} \mathbf{e}^{i}}
$$

where $\mathbf{C}_{\mathbf{d}}^{i^{-1}}$ is the inverse of the Covariance matrix of displacements in the $i$ th interferogram, and $\mathrm{e}^{i}=(1 . .1)^{T}$ is a unity vector with the same dimension as $\mathbf{u}_{\mathbf{o}}^{i \prime}$ and $\mathbf{u}_{\mathbf{m}}^{i}$.

[42] InSAR data contain spatially correlated phase noise caused by the random fluctuation of atmospheric phase delays from one SAR image to another. Fukushima et al. [2005] found they can be appropriately modeled by an exponential autocorrelation or covariance function, expressed as

$$
C(r)=\sigma_{d}^{2} \exp (-r / a)
$$


Table 2. Comparison of the Inversion Results ${ }^{\mathrm{a}}$

\begin{tabular}{|c|c|c|c|c|c|c|c|c|c|}
\hline & One Dike & $\begin{array}{l}\text { One Dike and } \\
\text { One Deflation } \\
\text { Source }\end{array}$ & $\begin{array}{l}\text { One Dike and } \\
\text { One Fault } \\
\text { Network }\end{array}$ & $\begin{array}{c}\text { Two Dikes, } \\
\text { Model (a) }\end{array}$ & $\begin{array}{l}\text { Two Dikes, } \\
\text { Model (b) }\end{array}$ & $\begin{array}{c}\text { Two Dikes, } \\
\text { Model (c) }\end{array}$ & $\begin{array}{l}\text { Two Dikes, } \\
\text { Model (d) }\end{array}$ & $\begin{array}{l}\text { Two Dikes, } \\
\text { Model (e) }\end{array}$ & $\begin{array}{l}\text { Two Dikes } \\
\text { Model (f)* }\end{array}$ \\
\hline $\begin{array}{l}\text { Number of } \\
\text { parameters } \\
\text { inverted }\end{array}$ & 6 & 12 & 17 & 9 & 10 & 11 & 12 & 13 & $14^{*}$ \\
\hline RMS error $(\mathrm{cm})$ & 4.8 & 4.2 & 3.5 & 2.7 & 2.6 & 2.6 & 2.6 & 2.5 & $2.3^{*}$ \\
\hline $\begin{array}{l}\text { Number of } \\
\text { acceptable } \\
\text { models }\end{array}$ & 1,750 & 6,220 & 6,450 & 4,130 & 6,810 & 6,210 & 9,430 & 12,460 & 20,200 \\
\hline AIC & 10563 & 9203 & 8694 & 7912 & 7821 & 7822 & 7897 & 7762 & $7753 *$ \\
\hline
\end{tabular}

${ }^{a}$ The asterisk denotes the preferred model. Parameters are described in Figure 7. Models are as follows: (a) Inverted parameters: for the eruptive fissure dike $P_{0}$, Dip, Botelv, Botlen, Twist; for the buried dike $P_{1}, D_{\text {top }}$, Strike and Toplen. (b) Same parameters as model (a) with Dip as an additional parameter for the buried dike. (c) Same parameters as model (a) with Dip and Botelv as additional parameters for the buried dike. (d) Same parameters as model (a) with Dip, Botelv and Botlen as additional parameters for the buried dike. (e) Same parameters as model (a) with Botang as extra parameter for the eruptive fissure dike and Dip, Botelv, and Botlen as extra parameters for the buried dike. (f) Same parameters as model (a) with Botang as extra parameter for the eruptive fissure dike and Dip, Botelv, Botlen and Botang as additional parameters for the buried dike.

where $C$ is either the autocorrelation or covariance function, $r$ is the distance between two pixels, $\sigma_{d}^{2}$ is the variance of the noise, and $a$ is the correlation distance [Fukushima et al., 2005]. Following Fukushima et al. [2005], we compute the autocorrelation function for the undeformed area of each interferogram and estimate the variance and correlation distance corresponding to the best exponential curve fit for each interferogram (Table 1). We then use these values to compute the full covariance matrix $\mathbf{C}_{\mathbf{d}}$ which we use for the misfit computation (2).

[43] The appraisal stage [Sambridge, 1999b] involves calculations of posterior probability density functions using misfit values calculated during the search stage. It allows for the estimation of several model statistical characteristics such as the mean model and marginal posterior probability density functions (PPDs). The one-dimensional marginal PPDs provide confidence intervals for the model parameters, while the two-dimensional marginal PPDs indicate trade-offs between pairs of model parameters. The applicability of the method has been confirmed by synthetic tests [Fukushima et al., 2005].

\section{Most Likely Model for the 2002 Nyiragongo Eruption}

[44] The complex displacements observed could result from a combination of sources. Possible deformation sources are suggested by the observation of the various geological and geochemical changes associated with the eruption. The eruptive fissure indicates that one of the sources is a dike. The fact that methane and $\mathrm{CO}_{2}$ were released [Komorowski et al., 2002/2003] could indicate the partial draining of a gas reservoir. The seismic activity associated with the eruption suggests that faults may have been involved in the eruption. Finally, the geochemical data also indicates the presence of another magma reservoir, or a second, deeper dike [Tedesco et al., 2007].

[45] Because the misfit function used in the inversion only gives a relative comparison of the data fit of models, we discuss the models using $R M S$ errors, which are a more intuitive indicator. They are defined as:

$$
R M S=100 * \sqrt{\frac{\left(\mathbf{u}_{\mathbf{o}}-\mathbf{u}_{\mathbf{m}}\right)^{T}\left(\mathbf{u}_{\mathbf{o}}-\mathbf{u}_{\mathbf{m}}\right)}{N}}
$$

where $N$ is the number of subsampled data points. The $R M S$ error is expressed in centimeters.

[46] Generally, when inverting for model parameters, increasing the number of model parameters decreases the misfit. However, the lowest misfit model determined is not necessarily the correct one. In order to select the most likely model, we use the Akaike information criterion (AIC) [Akaike, 1974] which is defined as

$$
A I C=2 \mathrm{k}+\chi^{2}+C^{s t e}
$$

where $C^{\text {ste }}$ is a constant, $C^{\text {ste }}=\log \left|\mathbf{C}_{\mathbf{d}}\right|+N \log (2 \pi)$. $\mathrm{k}$ is the number of inverted parameters, $\chi^{2}$ is the misfit defined in equation (2), and || stands for the determinant. The $A I C$ allows models to be selected according to their relative value, in such a way that the most likely model has the lowest $A I C$. As $C^{\text {ste }}$ is the same for all models, it will be ignored in the model comparison.

\subsection{Rejected Models}

[47] Models considering one single dike (Table 2, column 1, and descriptions, and Figure S4 and Table S1 in the auxiliary material) or a dike and a deflating reservoir beneath the Goma area (Table 2, column 2, and descriptions, and Figure S5 and Table S2 in the auxiliary material) do not fit the InSAR data satisfactorily, leading to $R M S$ errors of 4.8 and $4.2 \mathrm{~cm}$, respectively. Thus they were rejected.

[48] Models considering a dike and several faults were also rejected (Figure S6 and Table S3 in the auxiliary material). In contrast to the 2007 Natron basin seismomagmatic event [Baer et al., 2008; Calais et al., 2008; Biggs et al., 2009], field observations performed after the Nyiragongo eruption [Komorowski et al., 2002/2003] showed no significant fault trace, with the exception of the two $2.5 \mathrm{~km}$ long $1 / 3$ fringe discontinuities visible in the RADARSAT-1 descending interferogram in the Gisenyi area (Figure 5 and section 6.3). Inversions considering a dike associated with the 2002 eruptive fissure and one to three westward-dipping normal faults located to the west of this dike led to a poor data fit with a $R M S$ error of $3.5 \mathrm{~cm}$ (Table 2, column 3 ).

\subsection{Preferred Model}

[49] Our best fit model consists of a shallow dike associated with the eruptive fissure, and a second, deeper dike, 

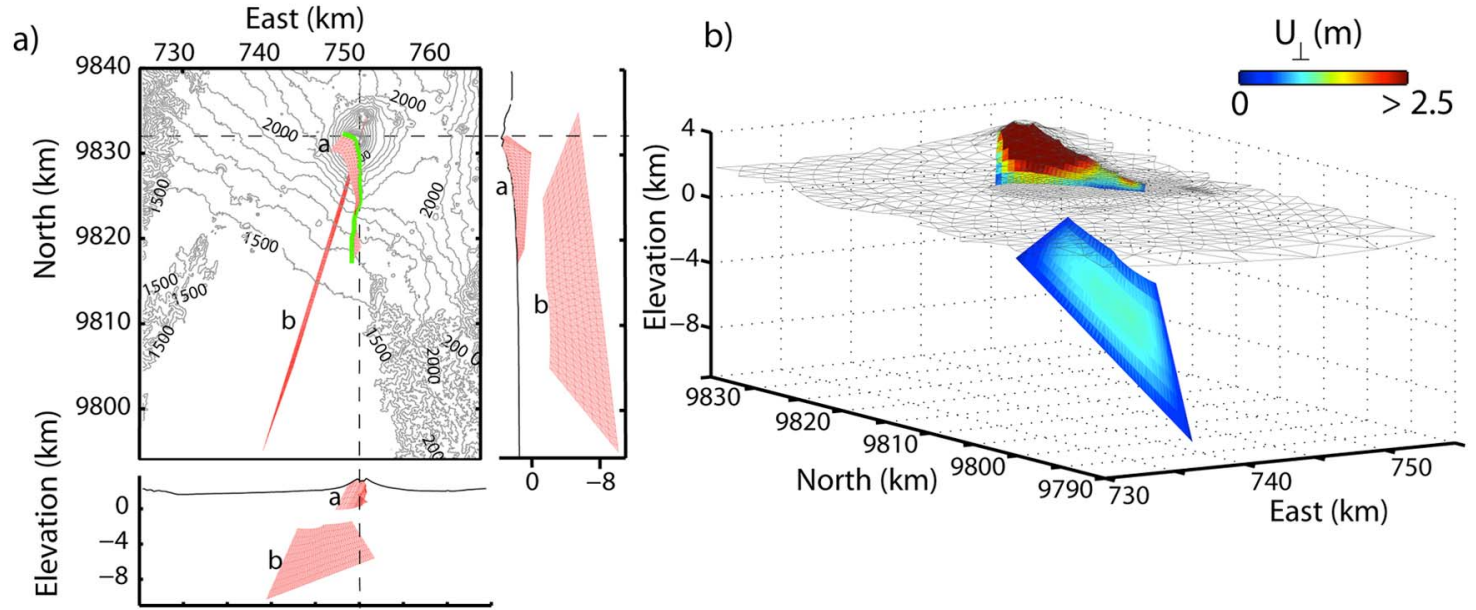

Figure 8. (a) Three views of the geometry of the preferred two-dike model. The view with contour lines is a map view. The dashed lines in the map view indicate the locations of the vertical cross-sections shown to the right of, and below, this view. The view to the right is the north-vertical cross-section and the view below is the east-vertical cross-section. The 2002 eruptive fissure is mapped in green. (b) Topographic mesh used for the modeling and 3D view of the two-dike intrusions described in Tables $3 \mathrm{a}$ and $3 \mathrm{~b}$ and section 5.2. The opening of each element is adjusted so that it fits the constant stress boundary condition in the boundary element computation.

with its northern end located beneath the Nyiragongo edifice, extending below Lake Kivu, and ending about $15 \mathrm{~km}$ from Idjiwi Island. Because of the lack of InSAR measurements over the lake surface, we assessed the position of the southern end of the deep dike based on the coherent InSAR data along the shore. It was fixed by trials and errors in the preliminary inversions. A reasonable data fit was found with the southern end of the deep dike located at $743 \mathrm{~N}$ and 9,805 E km UTM (Table 3b). The northern end of the deep dike is defined by two parameters (Strike and Toplen) that are inverted.

[50] In order to determine the most likely model, we performed six inversions, increasing the number of inverted parameters from 9 to 14 (Table 2, models (a) to (f)). Each inversion involved several thousand models (Table 2). The more complex the model, the larger the number of forward models required for the inversion to converge (Table 2). The 14 parameter model (Figure 8 and Table 2, model (f)*) is the most likely as it has the lowest $A I C$. It has the best data fit as it is associated with the lowest $R M S$ error (2.3 cm, Table 2). With this model, the dike connected to the eruptive fissure is subvertical and shallow, with an average height of $2 \mathrm{~km}$ and a sub-horizontal bottom, making the dike nearer to the surface beneath Nyiragongo volcano (Figure 8 and Table 3a) than beneath the city of Goma. The dike is associated with an overpressure of $0.9 \mathrm{MPa}$. The opening distribution corresponding to this overpressure is maximum at the ground surface (Figure 8b), where the mean opening is $3 \mathrm{~m}$, a value which is consistent with field measurements [Komorowski et al., 2002/2003]. The other dike is deeper and has a $20 \mathrm{~km}$-long top at a depth of $3.3 \mathrm{~km}$ below the surface, an average height of $6 \mathrm{~km}$, and a $40 \mathrm{~km}-\mathrm{long}$ bottom (Figure $8 \mathrm{a}$ and Table $3 \mathrm{~b}$ ). Like the shallower dike, the deeper dike has a low overpressure of $0.4 \mathrm{MPa}$. The corresponding opening is at its maximum toward the center of the dike, reaching $1 \mathrm{~m}$, with an average value of $0.7 \mathrm{~m}$ (Figure $8 \mathrm{~b}$ ). The two-dimensional PPDs (Figure S7 in the auxiliary material) show that there are no significant trade-offs between the model parameters.

[51] To the west of the 2002 eruptive fissure, residuals (Figure 9) are lowest on the shortest time-span interferogram. This indicates that time-dependent processes, such as a slow motion of the rift border faults or magma movements associated with Nyamulagira's 2002 eruption, might also have taken place. Other residuals, in the Goma area and east

Table 3a. Best Fit Parameters for the Preferred Model (Two Dikes With 14 Model Parameters (f)*) Given With Their 95\% Confidence Intervals: Quadrangular Shallow Dike Connected to the Ground ${ }^{\mathrm{a}}$

\begin{tabular}{|c|c|c|c|c|c|c|c|c|c|}
\hline & $P_{0}(\mathrm{MPa})$ & Botelv (km a.s.l) & $\operatorname{Dip}\left(^{\circ}\right)$ & Shear $\left(^{\circ}\right)$ & Botlen & Botang $\left(^{\circ}\right)$ & Twist $\left(^{\circ}\right)$ & $\begin{array}{c}\text { Surf. Av. } \\
U_{\perp}{ }^{b}(\mathrm{~m})\end{array}$ & $\begin{array}{c}\text { Av. } \\
U_{\perp}^{\mathrm{b}}(\mathrm{m})\end{array}$ \\
\hline Search int. & {$[0.2 ; 2.5]$} & {$[-1 ; 1.5]$} & {$[80 ; 140]$} & fixed & {$[0.3 ; 1.3]$} & {$[-30 ; 30]$} & {$[-10 ; 40]$} & - & - \\
\hline Best fit & 0.9 & 0.33 & 105 & 0 & 0.78 & -4 & 14 & 3 & 2.1 \\
\hline $95 \%$ conf. int. & {$[0.87 ; 0.94]$} & {$[0.28 ; 0.36]$} & {$[104 ; 106]$} & fixed & {$[0.76 ; 0.8]$} & {$[-5.1 ;-3]$} & {$[13.2 ; 14.7]$} & - & - \\
\hline
\end{tabular}

${ }^{\text {a }}$ Parameters are described in Figure 7.

${ }^{\mathrm{b}} U_{\perp}$ is the opening. 
of Lake Kivu, are probably due to the oversimplified shapes of the dikes considered in the inversions.

\section{Discussion}

\subsection{Bias Induced by the Homogeneous Elasticity Hypothesis}

[52] A low value of the Young's modulus was considered for the inversions of both dikes ( $E=5 \mathrm{GPa}$ ), corresponding to the Young's Modulus in the upper two kilometers of the crust. Although this is a reasonable assumption for the shallow dike, such a low value could lead to an underestimation of the depth of the deeper dike. Models with depthdependent elastic properties, with more compliant layers at shallow depth and stiffer layers at greater depth, always lead to over-estimations of source depths, whether these sources are shear faults [Arnadottir et al., 1991; Montgomery-Brown et al., 2009] or magmatic reservoirs [Masterlark, 2007].

[53] This low Young's modulus might also lead to an underestimation of the overpressure of the deep dike. Considering the depth-dependent rigidity estimated earlier for this area (section 4.1 and Figure 6f), the Young's modulus reaches an average value of $90 \mathrm{GPa}$ at $4 \mathrm{~km}$ depth, which is the mean depth of the deep dike (Table 3b). When inverting displacements for overpressures in linear elastic media, the determined overpressures are linear functions of the Young's modulus. Thus, if the Young's modulus is $E=90 \mathrm{GPa}$ instead of $E=5 \mathrm{GPa}$ used in the inversions, the overpressure of the deep dike is $7.4 \mathrm{MPa}$, instead of $0.4 \mathrm{MPa}$.

\subsection{Consistency With Lake Level Data}

[54] In order to compare lake level data with the InSAR observations and our best fit deformation model, the InSAR displacements from the three beams were simultaneously used to compute vertical displacements along the lake shore following the procedure of Wright et al. [2004]. Before computing vertical displacements the InSAR displacements were shifted by the amount that minimized the misfit between the observed data and the best fit model (equation (3)). Standard deviations and unit LOS vectors considered for the displacement calculations are given in Table 1. Comparison of the vertical displacement of the lake shore as determined from the best fit model, the InSAR data and the water level measurements (Figure 3) shows a similar overall shape of subsidence characterized by a maximum subsidence at approximately the same location. Lake level data show a maximum subsidence of $32 \mathrm{~cm}$ relative to the easternmost point of the northern shore of Lake Kivu [Tedesco et al., 2007], greater than the modeled $(8 \mathrm{~cm})$ or InSAR measured $(5 \mathrm{~cm})$ relative subsidences. In addition, whereas the lake level data indicate only broad subsidence, the InSAR data and associated model predict uplift on each side of the subsiding sector. Due to the large uncertainties in the lake level measurements, we attribute the discrepancies between the model, InSAR data and the lake level measurements to errors in the latter.

\subsection{Discontinuities in the Gisenyi Area}

[55] In order to test whether these faults could have been activated by the 2002 dikes, we have computed the expected 


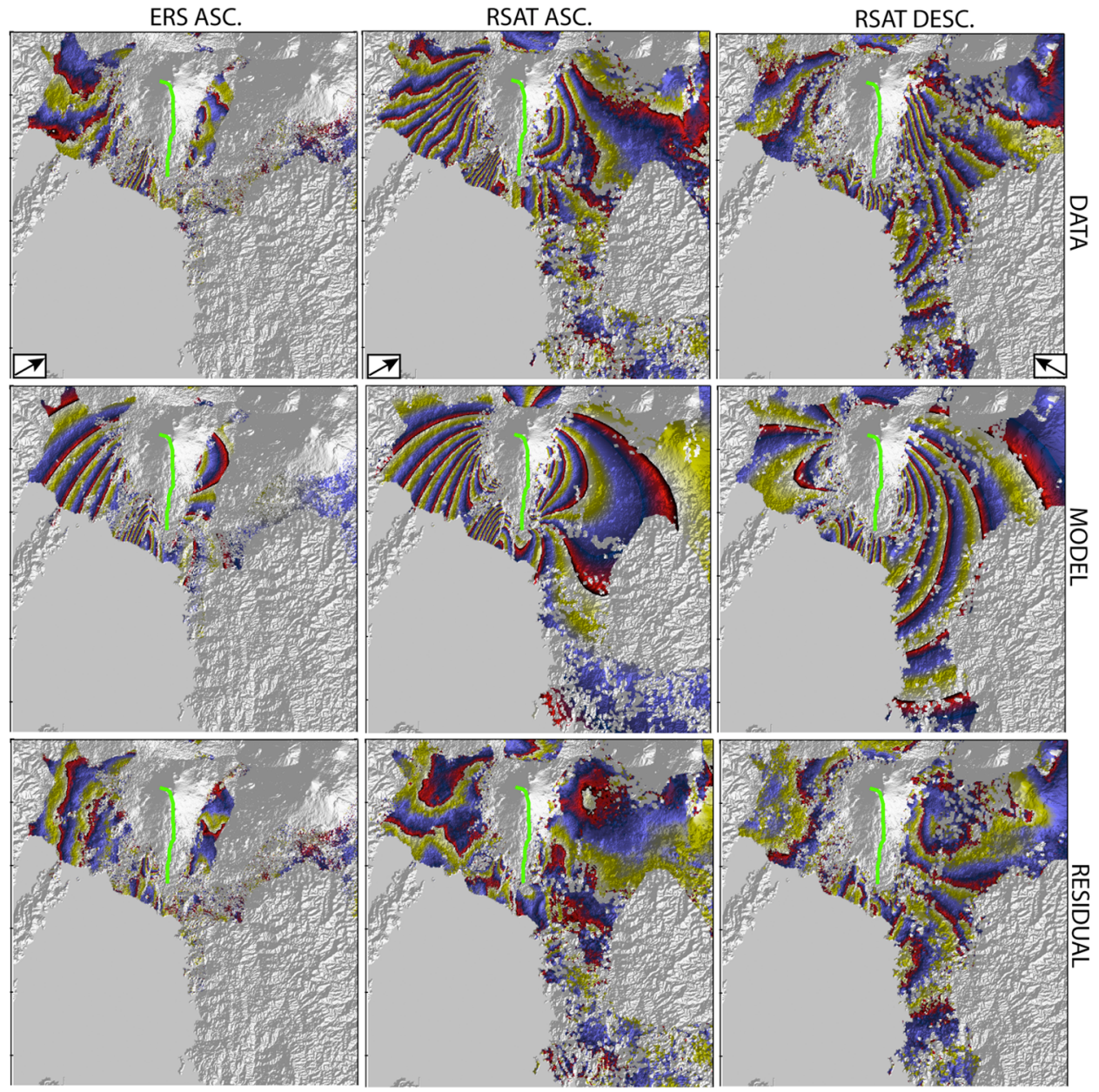

Figure 9. Observed, modeled and residual interferograms obtained with the best fit model considering two-dike intrusions. This model also gives the lowest $A I C$. Location of this area is indicated by a box in Figure 2a.

static stress changes as follows. Coulomb stress changes $\Delta S$ are given by

$$
\Delta S=\Delta \tau-\mu^{\prime} \Delta \sigma
$$

where $\Delta \tau$ is the shear stress change on failure planes with a given orientation and rake (positive in the sense of slip), $\Delta \sigma$ is the change in normal stress, and $\mu^{\prime}$ is the effective friction coefficient which incorporates the effect of pore fluids. Following Stein et al. [1992] and King et al. [1994] a value of 0.4 is assumed. No attempt is made to investigate the influence of this parameter as several studies have concluded that Coulomb stress modeling is only marginally dependent on the effective friction coefficient values [King et al., 1994; Parsons et al., 2012]. As the Gisenyi discontinuities are parallel to the normal faults at the eastern rift border (Figure 2), which are west dipping, they are assumed to be the surface expression of the border faults. A dip of $60^{\circ}$ is assumed as it is the most common dip for normal faults. A Coulomb stress calculation performed with the MBEM (Figure 10) shows that the discontinuities are located in an area where slip on normal faults would be promoted. These faults are too far from the dikes to be located

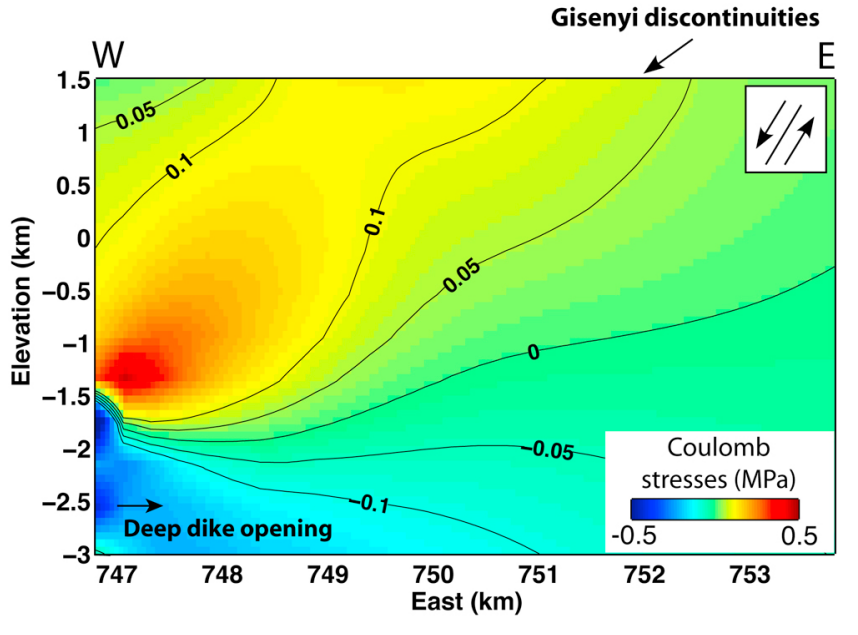

Figure 10. Coulomb stress changes corresponding to the best fit two-dike model (see Figure $2 \mathrm{~b}$ for the profile location). Effective friction coefficient is $=0.4$. Positive values indicate that normal fault slip is promoted. The area where the Gisenyi discontinuities have been observed (Figure 5) is indicated with an arrow. 
Table 4. Elevation of the Nyiragongo Lava Lake, Intruded Magma Volume and Erupted Lava Volumes Estimated for the 1977 and 2002 Eruptions $^{\mathrm{a}}$

\begin{tabular}{|c|c|c|c|c|}
\hline & $\begin{array}{l}\text { Nyiragongo Lava Lake Altitude } \\
\text { Below the Rim (m) }\end{array}$ & $\begin{array}{l}\text { Volume Drained From } \\
\text { the Crater }\left(\times 10^{6} \mathrm{~m}^{3}\right)\end{array}$ & $\begin{array}{l}\text { Intruded Magma } \\
\text { Volume }\left(\times 10^{6} \mathrm{~m}^{3}\right)\end{array}$ & $\begin{array}{l}\text { Total Erupted Lava } \\
\text { Volume }\left(\times 10^{6} \mathrm{~m}^{3}\right)\end{array}$ \\
\hline 2002 & $250[$ Durieux, 2002/2003] & 60 [Komorowski et al., 2002/2003] & $\begin{array}{c}60^{\mathrm{b}}[\text { Komorowski et al. }, 2002 / 2003] \\
136 \text { in the deep dike }+74 \text { in the } \\
\text { shallow dike }=210 \text { [this study }]\end{array}$ & $14-34^{\mathrm{c}}$ [Tedesco et al., 2007] \\
\hline 1977 & 155 [Tedesco et al., 2007] & $\begin{array}{c}234 \text { [Tazieff, 1977; } \\
\text { Komorowski et al., 2002/2003] }\end{array}$ & $\begin{array}{c}212^{\mathrm{d}}[\text { Tazieff, } 1977 ; \\
\text { Komorowski et al., 2002/2003] }\end{array}$ & $\begin{array}{c}22^{\mathrm{c}} \text { [Tazieff, 1977; } \\
\text { Komorowski et al., 2002/2003] }\end{array}$ \\
\hline
\end{tabular}

\footnotetext{
The crater rim is located at $3,425 \mathrm{~m}$ above sea level.

${ }^{\mathrm{b}}$ Estimated from the volume drained from the crater lava lake.

${ }^{\mathrm{c}}$ Estimated from the lava flow volume.

${ }^{\mathrm{d}}$ Estimated from drained minus lava flow volumes.
}

in the area of greatest Coulomb stress increase. Thus, most probably, these faults were not created by the dike intrusions, but reactivated by them. As the observed displacements have a small amplitude and extend over a small area, it is likely that the faults were only reactivated to a shallow depth.

\subsection{Magma Origin}

[56] The two-dike model with a shallow and deep dike is consistent with the two reservoirs inferred from petrographical and seismic analysis. The shallow dike goes down to $3 \mathrm{~km}$ below the summit, a depth consistent with the shallow reservoir depth estimated to lie between $4 \mathrm{~km}[$ Platz et al., 2004] and $1 \mathrm{~km}$ [Louaradi, 1994] based on leucite crystallization pressure. The $12 \mathrm{~km}$ maximum depth below the surface for the deep dike is consistent with the calculated value for the deep reservoir of 10-14 km depth, as determined from petrographical analysis on fluid and melt inclusions in olivine and clinopyroxene phenocrysts [Demant et al., 1994], as well as the a-seismic region [Tanaka, 1983].

[57] The model is also consistent with ${ }^{38} \mathrm{U}$ and ${ }^{232} \mathrm{Th}$ series radioactive disequilibria data, calculated from lavas emitted during the eruption [Tedesco et al., 2007], which suggest that the eruption was fed by up to three different magmatic sources. These authors infer that the northern lava flows were probably supplied by the lava lake and a shallow magma reservoir, while the southern lava flows were related to a second, deeper reservoir, probably located beneath Goma city and Lake Kivu. The shallow dike volume is consistent with this model as the inverted shallow dike has a slightly greater volume $\left(74 \times 10^{6} \mathrm{~m}^{3}\right.$, Table 4$)$ than the volume of lava that drained from the summit crater $(60 \times$ $10^{6} \mathrm{~m}^{3}$, Table 4 [Komorowski et al., 2002/2003]). Thus, it could have been supplied by other sources, such as a shallow or a deep reservoir.

[58] We do not see any evidence of a shallow or deep reservoir deflation, as suggested by the unusual earthquakes recorded during the eruption [Shuler and Ekström, 2009], but these deflations could have been hidden by the large displacements associated with the dike intrusion, or by the lack of coherent InSAR data on the steep vegetated slopes of the volcano and on Lake Kivu. The pressure in the reservoir could also have been restored by gas exsolution in the magma chamber [Rivalta and Segall, 2008].

[59] In our preferred model, the deep dike is not connected to the ground or to the other dike (Figure 8). However, the two dikes are only separated by about $2 \mathrm{~km}$ vertically, so the presence of a magma conduit between them is highly likely. The connection between both dikes is probably via another dike, as this is the most efficient means of transporting magma through the lithosphere [Rubin, 1995; Delaney and Pollard, 1981]. This dike might be too narrow to cause detectable InSAR displacements. Indeed, the data fit breaks down when the southernmost part of the shallow dike is shortened by $5 \mathrm{~km}$ and replaced with a $5 \mathrm{~km}$-long dike connecting the eruptive fissure to the deep dike. A similarly narrow path is also postulated for other volcanoes such as Piton de la Fournaise [Fukushima et al., 2010; Traversa et al., 2010].

\subsection{Eruption Model}

[60] In order to distinguish whether the deep or the shallow dike has the most influence on the opening of the other one, we use the MBEM to compute normal stress changes induced by each inverted dike on the other. For these computations, we use the uncorrected overpressures $P_{0}=0.9 \mathrm{MPa}$ and $P_{1}=0.4 \mathrm{MPa}$ determined for the shallow and deep dike (Tables $3 \mathrm{a}$ and $3 \mathrm{~b}$ ), respectively, considering a homogeneous medium with a Young's modulus $E=5 \mathrm{GPa}$, as in the inversions. Induced normal stresses are computed at the centroid of each triangular boundary element. Figure 11 shows that each dike decreases the normal stresses of the other. The shallow dike mainly decreases the normal stresses on the upper, northern part of the deep dike (Figure 11a), while the deep dike mainly decreases normal stresses on the southern part of the shallow dike in an area extending from the bottom of the dike to the surface (Figure 11b).

[61] Geophysical observations [Battaglia et al., 2005], numerical [Dahm, 2000] and analog models [Rivalta and Dahm, 2005] indicate that dikes grow upward or laterally from the source region. Thus it is unlikely that the stress changes induced by the shallow dike would promote the injection of magma downward to the deeper dike. Conversely, the stress decrease induced by the deep dike could favor the injection of magma from the deep dike up into the shallow dike. The area of maximum stress decrease is coincident with the area where radioactive disequilibria indicate a different magmatic source to that of the northern part of the eruptive dike [Tedesco et al., 2007]. Moreover, the deep dike induces a $0.07 \mathrm{MPa}$ pressure decrease in the host rocks at the level of the shallow reservoir, corresponding to an overpressure increase in the reservoir. If the reservoir is at a critical equilibrium and connected to the summit lava lake, as indicated by the petrographical data [Demant et al., 1994], this stress change might be sufficient to initiate the reservoir and magma column failure, triggering the intrusion of a shallow dike. 


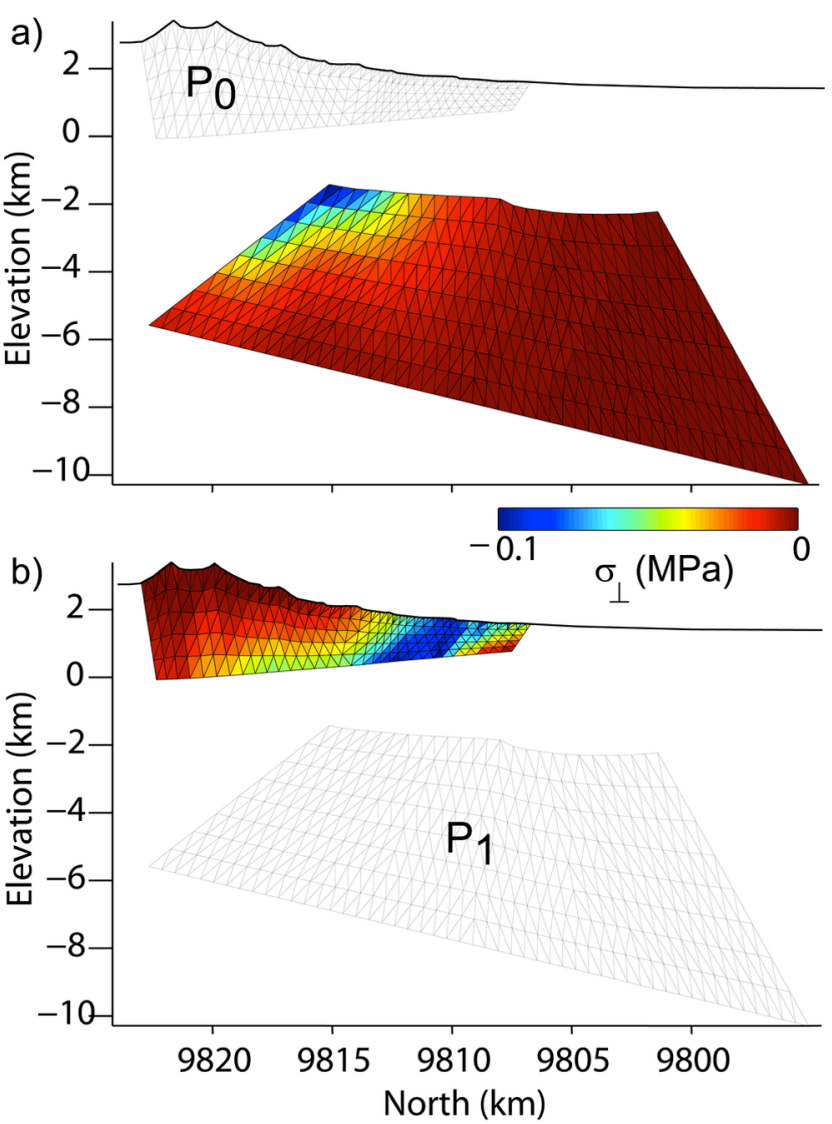

Figure 11. Normal stresses induced by one dike on the other along a north-south cross-section: (a) Normal stress $\left(\sigma_{\perp}\right)$ in MPa induced on the deep dike by pressure from the shallow dike. (b) Normal stress $\left(\sigma_{\perp}\right)$ in MPa induced on the shallow dike by pressure from the deep dike.

[62] A likely scenario (Figure 12) is that the eruption was initiated by the supply of magma to a deep reservoir, ten months before the eruption, as suggested by the increased number of long period earthquakes and the onset of continuous harmonic tremor before the eruption [Kavotha et al., 2002/2003]. Such an early supply is also consistent with the model of lava flow rheology which indicates that lavas emitted on the southernmost fissure had probably been cooled in the weeks or months before the eruption [Giordano et al., 2007]. This deep reservoir might have subsequently fed the deep dike.

[63] As indicated by our stress analysis, the intrusion of the deep dike could have promoted tensional failure of the shallow reservoir. As this reservoir is permanently connected to the lava lake [Demant et al., 1994], failure of the reservoir could have induced the opening of the shallow dike and the subsequent draining of the lava lake.

[64] Lavas from the lava lake were emitted first as they were closer to the surface and their magmastatic pressures promoted dike opening, followed by lavas from the shallow reservoir. Draining of the shallow reservoir could have induced failure of the top of this reservoir along ring dikes, leading to the unusual earthquakes recorded during the eruption [Shuler and Ekström, 2009]. Even if the deep intrusion was initiated first, it might only have breached the surface after the shallower intrusion since it was further from the surface. Since fracture toughness is depth-dependent [Rivalta and Dahm, 2006] the deeper intrusion probably propagated to the surface more slowly than the shallow intrusion. The presence of the deep dike could have facilitated the connection between the deep dike and the southern part of the shallow dike, leading to the eruption of magma from the deep source south of the eruptive fissure. This scenario involving the lava lake, a shallow reservoir and a deep reservoir for the southernmost fissure is consistent with the geochemical analysis and model of Tedesco et al. [2007].

[65] Injection of magma into a deep dike could have triggered the precursory and post-eruptive short- period earthquakes [Kavotha et al., 2002/2003; Tedesco et al., 2007] by inducing slip on faults close to the dike tip which were on the verge of failure [Rubin, 1992]. This has often been observed during dike intrusions, for instance in Afar in 2006 [Grandin et al., 2009; Keir et al., 2009], at the volcanic island of Izu in 2000 [Nishimura et al., 2001] or during the 2007 Natron faulting and diking event [Baer et al., 2008; Calais et al., 2008; Biggs et al., 2009]. Large earthquakes, such as the 3 February $20025.9 \mathrm{M}_{\mathrm{w}}$ Bukavu event [d'Oreye et al., 2011], or the October 24, $20026.2 \mathrm{M}_{\mathrm{w}}$ south Lake Kivu event (Figure S8 in the auxiliary material), might remain undetected by interferometry if they were to occur beneath Lake Kivu or in areas of low coherence.

[66] On the 9 descending and 8 ascending available RADARSAT-1 interferograms that cover the year before the eruption, we do not see any evidence of pre-eruptive inflation of a deep reservoir, but it might go undetected if it was too deep or associated with only a small volume increase, or because the area affected by the magma injection was incoherent, as would be the case if it was located beneath Lake Kivu.

[67] The lack of seismic and continuous geodetic measurements prevents us from tracking the progression of magma at depth. Therefore, compared to better-studied rifting events, such as the Manda-Hararo 2005-2010 diking events [Keir et al., 2009; Grandin et al., 2010] or the Puu' Oo 1983 eruption [Rubin et al., 1998], it is not possible to detect if the deep dike was fed by a mid-segment reservoir.

\subsection{Comparisons With the 1977 Eruption}

[68] The 2002 eruption has many common characteristics with the 1977 event. Both eruptions are associated with riftparallel fissure networks, indicating that the intrusion directions are related to the direction of rift extension.

[69] The two estimated erupted lava volumes are similar (Table 4, column 4), and, in both eruptions, the summit lava lake drained. In 1977 the lava lake level was about $155 \mathrm{~m}$ below the crater rim, whereas it was about $250 \mathrm{~m}$ below the rim before the 2002 eruption (Table 4, column 1). Not only was the lava lake level higher in 1977 than in 2002, but the diameter of the drained crater was wider in the former [Durieux, 2002/2003], leading to a much larger estimate for the drained volume in $1977\left(234 \times 10^{6} \mathrm{~m}^{3}\right)$ [Tazieff, 1977] compared to $2002\left(60 \times 10^{6} \mathrm{~m}^{3}\right)$ [Komorowski et al., 2002/ 2003] (Table 4, column 2).

[70] For the 1977 eruption, an intruded volume of $212 \times$ $10^{6} \mathrm{~m}^{3}$ was estimated from the difference between the drained lake and the lava flow volumes [Komorowski et al., 2002/2003; Tazieff, 1977]. Following the same approach, an intruded volume of $60 \times 10^{6} \mathrm{~m}^{3}$ was estimated from the 


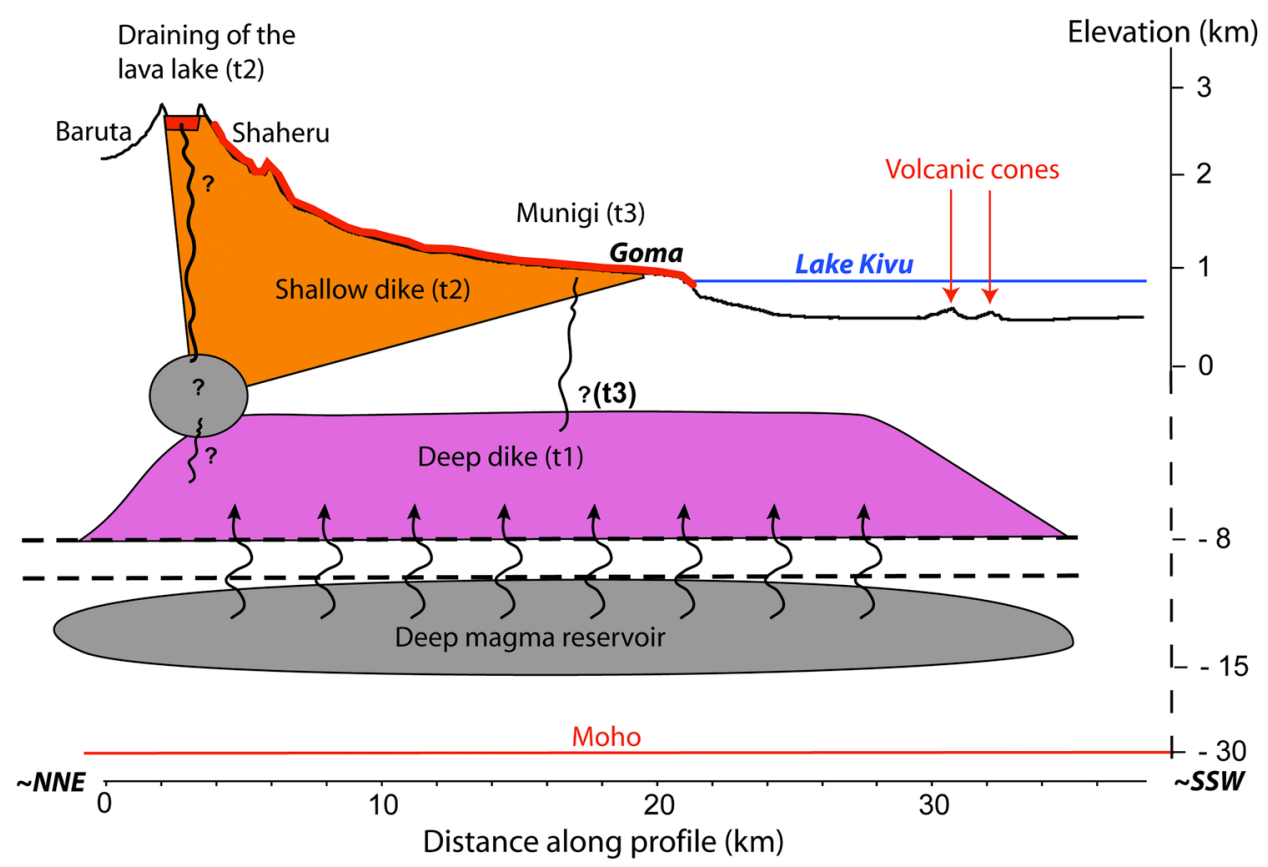

Figure 12. Schematic magmatic plumbing system beneath the Nyiragongo volcano and the northern part of Lake Kivu, and possible eruption chronology, inferred from the modeling and consistent with a previous study by Tedesco et al. [2007]. The topographic profile (black bold line) is obtained from the topographic and bathymetric data along the trace of the deep dike (Figure 2). The figure is not scaled for depth below sea level.

drained volume in 2002 (Table 4, column 3) [Komorowski et al., 2002/2003]. However, inverting for InSAR data, we found that both a shallow and a deep dike were involved in this eruption, leading to an intruded volume of $210 \times$ $10^{6} \mathrm{~m}^{3}$, more than three times larger than this estimate. Our modeling is consistent with the lava lake draining into the shallow dike. This shows that, when estimating magma volumes, volumes drained from the lava lake should be considered as minimum volume estimates as they do not account for magma supplied by reservoirs.

[71] The 1977 eruption appears to have induced a 2.4-fold increase in eruption rates at neighboring Nyamulagira volcano [Burt et al., 1994; Wadge and Burt, 2011], while the 2002 eruption may have decreased the lava output rate at Nyamulagira [Wadge and Burt, 2011]. Large dikes, such as the ones in this study, imply stress perturbations at a rift scale that could also affect the $15 \mathrm{~km}$-distant Nyamulagira volcano and change its eruption rate or its intruded versus extruded magma volume. Deformation associated with the 1977 eruption was not measured, so the exact perturbation related to this event cannot be investigated and compared with that of the 2002 eruption.

\subsection{Isotropic Lithostatic Crustal Stresses}

[72] The deep dike overpressure is smaller than values estimated in areas where extension is accommodated by normal faulting. Horizontal stresses needed for slip on faults correspond to a critically stressed crust with hydrostatic pore pressure [Rubin, 1990; Buck, 2006; Townend and Zoback, 2000]. In this case, Rubin [1990] estimated that an average overpressure of $54 \mathrm{MPa}$ could be reached at $5 \mathrm{~km}$ depth.
However, the overpressures we determined are close to values estimated when the stress state in the crust is lithostatic and isotropic, such that the horizontal compressive stress equals the rock pressure. If the rock stress close to the dike was lithostatic and isotropic, the overpressure at the center of the dike $z_{d}$ (corresponding to the mean overpressure), would be the difference between the magma and rock pressure:

$$
\Delta P\left(z_{d}\right)=\int_{z_{\min }}^{z_{\max }}\left(\rho_{m}-\rho_{r}\left(z^{\prime}\right)\right) g d z^{\prime},
$$

where $z_{\max }$ and $z_{\min }$ are the maximum and minimum depths of the dike, $\rho_{m}$ is the magma density and $\rho_{r}\left(z^{\prime}\right)$ is the rock density, linearly varying with depth, as indicated in Figure 6b. $g$ is the acceleration of gravity.

[73] For the estimation of the magma density, we consider that the magma is degassed. The InSAR displacements cover a six-month period extending from the eruption until midJuly 2002, during which time the $\mathrm{SO}_{2}$ emission rates were low. This led Carn [2002/2003] to assume that the emitted magma had been degassed during the long residence time in the crater and upper conduit of the volcano. For the degassed magma density in the shallow dike, we take a value of $\rho_{m}=2650 \mathrm{~kg} / \mathrm{m}^{3}$, which is the nephelinite density at Nyiragongo [Carn, 2002/2003], and for the magma density of the deep dike we take $\rho_{m}=2800 \mathrm{~kg} / \mathrm{m}^{3}$.

[74] Equation (8) allows us to determine that the overpressure corresponding to lithostatic isotropic stresses are 1.1 MPa, and 4.5 MPa for the shallow and deep dikes, 
respectively. These values are close to the overpressures estimated from the inversion of ground displacements, which are $0.9 \mathrm{MPa}$ for the shallow dike (Table 3a) and 7.4 $\mathrm{MPa}$ for the deep dike, after correcting for the low Young's modulus used for the inversions (section 6.1). Our analysis indicates that, close to the dikes, stresses are incompatible with the tensional tectonic stresses needed to produce stretching via normal faulting [Buck, 2006; Rubin, 1990; Townend and Zoback, 2000].

[75] If magma pressure was higher than the hydrostatic pressure assumed in equation (8), then the overpressure would be increased. The low overpressure we determined thus indicates that the magma pressure is low. This result is consistent with the observation that, in some places, magma was visible in the eruptive fissure without being actively erupted.

[76] Few studies of diking events document the overpressure, as most of them rely on kinematic inversions of geodetic data. Stress changes were determined for the different episodes of the 2005-2009 Afar rifting cycle by Grandin et al. [2010]. These authors did not invert surface displacements for stress changes but computed stress changes a-posteriori from the opening distribution, which is such that it represented the best compromise between the data fit and the smoothness of the dike opening. No assumption was made about the uniformity or depth dependence of overpressures, as would be expected for magma-filled fractures. Obtained stresses were very large at the center of the open patches, reaching $30 \mathrm{MPa}$ for a $5 \mathrm{~km}$-deep dike. We attribute the large overpressures obtained by Grandin et al. [2010] to the method they used for stress determination.

\subsection{Influence of the Rift Extension on the Dike Directions}

[77] Both dikes are subvertical and more or less perpendicular to the rift extension direction (Figure 1) [Stamps et al., 2008], the shallowest dike deviating more from the extension direction than the deeper dike. Northwest of the Nyiragongo edifice, the shallower dike follows the $\mathrm{N} 20^{\circ} \mathrm{W}$ weakness direction [Meyer, 1953] linking Nyamulagira and Nyiragongo, while further south the dike follows the northsouth direction taken during the course of the 1977 eruption. This direction is intermediate between the $\mathrm{N} 20^{\circ} \mathrm{W}$ weakness direction and the $\mathrm{N} 20^{\circ} \mathrm{E}$ rift direction, suggesting the combined effect of the two on the eruptive fissure emplacement. The fact that the direction of the deeper dike is perpendicular to the extension direction indicates that this dike direction is guided by the rift extension. As crustal stresses are found to be isotropic, it is likely that this direction is favored because of a reduced tensile strength inherited from previous dike intrusions rather than because it is a direction of minimum principal stress.

[78] The deeper dike is aligned to several other rift-related structures. For instance, it is aligned to the Idjiwi horst (Figure 2a), located south of Lake Kivu. Wong and Von Herzen [1974] showed that the horst structure extends up to the northern shore of the lake. The bounding fault of the horst could have guided the magma path. The deep dike could be connected to an undated Ngangi eruptive fissure (Figure 2b), $10 \mathrm{~km}$ west of the 2002 fissure, which strikes $\mathrm{N} 8^{\circ} \mathrm{E}$. This fissure is associated with the alignment of several eruptive cones and hornitos, and has localized uplift of about $10 \mathrm{~m}$, as confirmed by a field survey in January 2010. At the time of the January 2002 eruption, the local population reported smoke emissions along part of the Ngangi fissure. Eruptions beneath Lake Kivu are probably common since bathymetric data [Capart, 1955; Schmid et $a l ., 2010]$ indicate the presence of numerous old volcanic cones on the lake floor (Figure 2a). The southernmost cones are aligned with the deep dike, as determined from our inversions, indicating that this structure might have been active in the past and breached the lake floor.

\section{Conclusions}

[79] The major conclusions of our study of the 2002 Nyiragongo eruption using InSAR data can be summarized as follows:

[80] 1 . The best fit model describing the 2002 co-eruptive deformation, which is also the most likely, according to the Akaike information criteria, corresponds to two subvertical dike intrusions. The first, shallow dike, $2 \mathrm{~km}$ high on average, is associated with the $20 \mathrm{~km}$-long eruptive fissure. The modeled mean surface opening is $3 \mathrm{~m}$, which corresponds to field measurements. This dike volume is consistent with magmas originating from the summit lava lake combined with deeper sources. The second, deeper dike, $6 \mathrm{~km}$ high and located $3.3 \mathrm{~km}$ beneath the city of Goma, has a riftparallel strike, and a basal length of $40 \mathrm{~km}$. It is consistent with a deep magma source of the southernmost fissure. As this dike extends for about $20 \mathrm{~km}$ beneath the lake, it could have represented a considerable hazard if magma had reached the lake since its waters contain high concentrations of dissolved carbon dioxide and methane.

[81] 2. Given the precursory seismicity, it is likely that magma started to be supplied to a deep reservoir ten months before the eruption. From a stress transfer analysis, we find that the deep dike intrusion might have triggered the failure of a shallow reservoir and magma column beneath Nyiragongo lava lake, inducing the injection of lavas from the lava lake, magma column and shallow reservoir into the shallow dike. Our analysis indicates that the deep dike favored the opening of the southern part of the eruptive fissure, suggesting that magma from the deep dike was transmitted to the southern part of the eruptive fissure, through a dike too narrow to be detected. This model is consistent with geochemical analysis, the lava rheology, as well as the preeruptive and post- eruptive seismicity triggered on shallow faults by the intrusion of the deep dike. With the exception of the October 2002, 6.2 $\mathrm{M}_{\mathrm{w}}$ earthquake, these fault motions are not detectable on the interferograms, which could be explained by them occurring in the areas of decorrelation or below Lake Kivu.

[82] 3. Low overpressures are determined for both dikes, corresponding to crustal stresses which are close to being lithostatic and isotropic. The rift-parallel directions of the dikes, as well as their sub-vertical dips, indicate that their direction of emplacement is controlled by the rift extension. Because stresses are lithostatic, a low tensile strength inherited from previous intrusions is probably responsible for the intrusion direction. The alignment with numerous cones 
indicates that this direction is a preferential intrusion direction.

[83] Acknowledgments. RADARSAT-1 data are provided by Canadian Space Agency and Alaska Satellite Facility. ERS data were provided thanks to ESA Cat-1 nr 3224 and AO ALOS3690 projects, within the framework of various projects of the Belgian Science Policy (Belspo) and Luxembourg FNR such as the SAMAAV and GORISK projects (FNR STEREOII/06/01). The mapping of the 2002 eruptive fissures was carried out by Benoit Smets (RMCA) using a Ikonos image provided within the framework of the Beslpo GORISK SR/00/113 project, and a Spot image (source Spot Image), obtained by collaboration with the WWF (PNVi section). The 1977 eruptive fissures were mapped by Luc Tack (RMCA) using field observations, and geocoded by Benoît Smets. We warmly acknowledge Mike Poland for the access to RADARSAT-1 data. We also thank Eric Fielding and Matthew Pritchard for their help concerning the processing of RADARSAT-1 data with ROI-PAC. We acknowledge the help of Yo Fukushima and Jean-Luc Froger for the use of their inversion and meshing codes, respectively; and Dario Tedesco for data on the Lake Kivu levels. We thank Falk Amelung and an anonymous reviewer greatly for their thoughtful and useful reviews. Moreover, we benefited from fruitful discussions with Raphael Grandin, Benjamin Van Wyk de Vries and Cindy Ebinger concerning the tectonic setting of the area. Finally, we thank Frances Van Wyk de Vries for her help revising for English before and after the submission of the paper.

\section{References}

Adelinet, M., J. Fortin, Y. Guéguen, A. Schubnel, and L. Geoffroy (2010), Frequency and fluid effects on elastic properties of basalt: Experimental investigations, Geophys. Res. Lett., 37, L02303, doi:10.1029/ 2009GL041660.

Akaike, H. (1974), A new look at the statistical model identification, IEEE Trans. Autom. Control, 19(6), 716-723, doi:10.1109/TAC.1974.1100705.

Amelung, F., S. Jónsson, H. Zebker, and P. Segall (2000), Widespread uplift and trapdoor faulting on Galapagos volcanoes observed with radar interferometry, Nature, 407(6807), 993-996, doi:10.1038/35039604.

Arnadottir, T., P. Segall, and P. Delaney (1991), A fault model for the 1989 Kilauea south flank earthquake from leveling and seismic data, Geophys. Res. Lett., 18(12), 2217-2220, doi:10.1029/91GL02691.

Baer, G., Y. Hamiel, G. Shamir, and R. Nof (2008), Evolution of a magma driven earthquake swarm and triggering of the nearby Oldoinyo Lengai eruption, as resolved by InSAR, ground observations and elastic modeling, East African Rift, 2007, Earth Planet. Sci. Lett., 272, 339-352, doi:10.1016/j.epsl.2008.04.052.

Battaglia, J., V. Ferrazzini, T. Staudacher, K. Aki, and J.-L. Cheminée (2005), Pre-eruptive migration of earthquakes at the Piton de la Fournaise volcano (Réunion Island), Geophys. J. Int., 161, 549-558, doi:10.1111/ j.1365-246X.2005.02606.x.

Biggs, J., F. Amelung, N. Gourmelen, T. H. Dixon, and S.-W. Kim (2009), InSAR observations of 2007 Tanzania rifting episode reveal mixed fault and dyke extension in an immature continental rift, Geophys. J. Int., 179, 549-558, doi:10.1111/j.1365-246X.2009.04262.x.

Birch, F. (1966), Compressibility; elastic constant, in Handbook of Physical Constants, edited by S. P. Clark Jr., Mem. Geol. Soc. Am., 97, 97-173.

Buck, W. R. (2006), The role of magma in the developments of the AfroArabian Rift system, Spec. Publ. Geol. Soc., 259, 43-54.

Bürgmann, R., P. Rosen, and E. Fielding (2000), Synthetic aperture radar interferometry to measure Earth's surface topography and its deformation, Annu. Rev. Earth Planet. Sci., 28, 169-209, doi:10.1146/annurev. earth.28.1.169.

Burt, M. L., G. Wadge, and W. A. Scott (1994), Simple stochastic modelling of the eruption history of a basaltic volcano: Nyamuragira, Zaire, Bull. Volcanol., 56, 87-97.

Calais, E., et al. (2008), Strain accommodation by slow slip and dyking in a youthful continental rift, East Africa, Nature, 456, 783-787, doi:10.1038/nature 07478

Capaccioni, B., O. Vaselli, A. P. Santo, and M. M. Yalire (2002/2003), Monogenic and polygenic volcanoes in the area between the Nyiragongo summit crater and the lake Kivu shoreline, Acta Vulcanol., 14-15(1-2), 129-136.

Capart, A. (1955), L'échosondage dans les lacs du Congo Belge. Techniques et résultats acquis, Bull. Agric. Congo Belge, 46(5), 1075-1110.

Carn, S. A. (2002/2003), Eruptive and passing degassing of sulphur dioxide at Nyiragongo volcano (D.R. Congo): The 17 January 2002 eruption and its aftermath, Acta Vulcanol., 14-15(1-2), 75-86.
Cayol, V. (1996), Analyse élastostatique tridimenseionnelle du champs de déformations des édifices volcaniques par éléments frontières mixtes, $\mathrm{PhD}$ thesis, Univ. de Paris VII, Paris.

Cayol, V., and F. H. Cornet (1997), 3D mixed boundary elements for elastostatic deformations fields analysis, Int. J. Mech. Min. Sci. Geomech. Abstr., 34, 275-287, doi:10.1016/S0148-9062(96)00035-6.

Chen, C. W., and H. A. Zebker (2001), Two-dimensional phase unwrapping with use of statistical models for cost functions in nonlinear optimization, J. Opt. Soc. Am. A Opt. Image Sci. Vis., 18, 338-351, doi:10.1364/ JOSAA. 18.000338

Cheng, C. H., and D. H. Johnston (1981), Dynamic and static moduli, Geophys. Res. Lett., 8(1), 39-42, doi:10.1029/GL008i001p00039.

Chorowicz, J. (2005), The East African rift system, J. Afr. Earth Sci., 43, 379-410, doi:10.1016/j.jafrearsci.2005.07.019.

Colclough, S. (2005), Investigations of Nyamuragira and Nyiragongo volcanoes (DRC), using interferometric synthetic aperture radar, $\mathrm{PhD}$ thesis, Univ. of Cambridge, Cambridge, U. K.

d'Oreye, N., F. Kervyn, E. Calais, V. Cayol, J. Fernández, C. Frischknecht, P. Gonzales, S. Heleno, A. Oyen, and C. Wauthier (2008), Systematic InSAR monitoring of African active volcanic zones: What we have learned in two years, or an harvest beyond our expectations, in Second Workshop on USE of Remote Sensing Techniques for Monitoring Volcanoes and Seismogenic Areas, 2008. USERest 2008, pp. 1-6, IEEE, Washington, D. C., doi:10.1109/USEREST.2008.4740361.

d'Oreye, N., et al. (2011), Source parameters of the 2008 BukavuCyangugu earthquake estimated from InSAR and teleseismic data, Geophys. J. Int., 184, 934-948, doi:10.1111/j.1365-246X.2010.04899.x.

Dahm, T. (2000), Numerical simulations of the propagation path and the arrest of fluid-filled fractures in the Earth, Geophys. J. Int., 141, 623-638, doi:10.1046/j.1365-246x.2000.00102.x.

Delaney, P. T., and D. D. Pollard (1981), Deformation of host rocks and flow of magma during growth of minette dikes and breccia-bearing intrusions near Ship Rock, New Mexico, U.S. Geol. Surv. Prof. Pap., 1202, $61 \mathrm{pp}$.

Demant, A., P. Lestrade, R. T. Lubala, A. B. Kampunzu, and J. Durieux (1994), Volcanological and petrological evolution of Nyiragongo volcano, Virunga volcanic field, Zaire, Bull. Volcanol., 56, 47-61.

Denaeyer, M. E. (1963), Les hyaloclastites de la rive nord du lac Kivu (Congo), Bull. Volcanol., 25(1), 201-215, doi:10.1007/BF02596551.

Durieux, J. (2002/2003), Volcano Nyiragongo (D. R. Congo): Evolution of the crater and lava lakes from the discovery to the present, Acta Vulcanol., 14-15(1-2), 137-144.

Ebinger, C. J. (1989a), Tectonic development of the western branch of the East African rift system, Geol. Soc. Am. Bull., 101, 885-903, doi:10.1130/0016-7606(1989) $101<0885$ :TDOTWB >2.3.CO;2.

Ebinger, C. J. (1989b), Geometric and Kinematic development of border faults and 539 accommodation zones, Kivu-Rusizi Rift, Africa, Tectonics, 8(1), 117-133, doi:10.1029/TC008i001p00117.

Farr, T. G., et al. (2007), The shuttle radar topography mission, Rev. Geophys., 45, RG2004, doi:10.1029/2005RG000183

Fukushima, Y., V. Cayol, and P. Durand (2005), Finding realistic dike models from interferometric synthetic aperture radar data: The February 2000 eruption at Piton de la Fournaise, J. Geophys. Res., 110, B03206, doi:10.1029/2004JB003268.

Fukushima, Y., V. Cayol, P. Durand, and D. Massonnet (2010), Evolution of magma conduits during the 1998-2000 eruptions of Piton de la Fournaise volcano, Réunion Island, J. Geophys. Res., 115, B10204, doi:10.1029/ 2009JB007023.

Giordano, D., M. Polacci, A. Longo, P. Papale, D. B. Dingwell, E. Boschi, and K. Kasereka (2007), Thermo-rheological magma control on the impact of highly fluid lava flows at Mt. Nyiragongo, Geophys. Res. Lett., 34, L06301, doi:10.1029/2006GL028459.

Goldstein, R. M., and C. L. Werner (1998), Radar interferogram filtering for geophysical applications, Geophys. Res. Lett., 25(21), 4035-4038, doi:10.1029/1998GL900033.

Grandin R., et al. (2009), September 2005 Manda Hararo-Dabbahu rifting event, Afar (Ethiopia): Constraints provided by geodetic data, J. Geophys. Res., 114, B08404, doi:10.1029/2008JB005843.

Grandin, R., A. Socquet, E. Jacques, N. Mazzoni, J. B. de Chabalier, and G. C. P. King (2010), Sequence of rifting in Afar, Manda-Hararo rift, Ethiopia, 2005-2009: Time-space evolution and interactions between dikes from interferometric synthetic aperture radar and static stress change modeling, J. Geophys. Res., 115, B10413, doi:10.1029/2009JB000815.

Gudmundsson, A., and R. E. B. Andrew (2007), Mechanical interaction between active volcanoes in Iceland, Geophys. Res. Lett., 34, L10310, doi:10.1029/2007GL029873

Hanssen, R. F. (2001), Radar Interferometry: Data Interpretation and Error Analysis, Kluwer, Dordrecht, Netherlands. 
Kavotha, S. K., T. Mavonga, J. Durieux, and K. Mukambilwa (2002/2003), Towards a more detailed seismic picture of the January 17th, 2002, Nyiragongo eruption, Acta Vulcanol., 14-15(1-2), 87-100.

Keir, D., et al. (2009), Evidence for focused magmatic accretion at segment centers from lateral dike injections captured beneath the Red Sea rift in Afar, Geology, 37, 59-62, doi:10.1130/G25147A.1.

King, G. C. P., R. S. Stein, and J. Lin (1994), Static stress changes and the triggering of earthquakes, Bull. Seismol. Soc. Am., 84(3), 935-953.

Komorowski, J.-C., et al. (2002/2003), The January 2002 flank eruption of Nyiragongo volcano (Democratic Republic of Congo): Chronology, evidence for a tectonic rift trigger, and impact of lava flows on the city of Goma, Acta Vulcanol., 14-15(1-2), 27-61.

Louaradi, D. (1994), Etude isotopique (Carbone, oxygène) et microthermométrique (inclusions fluides et vitreuses) des magmas alcalins et carbonatitiques du rift Est africain et de la presqu'île de Kola, PhD thesis, Univ. de Paris VII, Paris.

Love, A. E. H. (1927), The Mathematical Theory of Elasticity, Cambridge Univ. Press, Cambridge, U. K. (Dover reprint, ISBN:0486601749).

Massonnet, D., and K. L. Feigl (1998), Radar interferometry and its application to changes in the earth's surface, Rev. Geophys., 36, 441-500, doi:10.1029/97RG03139.

Masterlark, T. (2007), Magma intrusion and deformation predictions: Sensitivities to the Mogi assumptions, J. Geophys. Res., 112, B06419, doi:10.1029/2006JB004860.

Mavonga, T. G. (2007), Some characteristics of aftershocks sequences of major earthquakes from 1994 to 2002 in the Kivu province, western Rift Valley of Africa, Tectonophysics, 439, 1-12, doi:10.1016/j. tecto.2007.01.006

Mavonga, T. G. (2010), Crustal structure beneath two seismic broadband stations revealed from teleseismic $\mathrm{P}$ wave receiver function analysis in the Virunga volcanic area, Western Rift, J. Afr. Earth Sci., 58, 820-828, doi:10.1016/j.jafrearsci.2009.11.003.

Meyer, A. (1953), Le volcan Nyamuragira et son éruption de 1951-1952, Bull. Inst. R. Col. Belges, 24, 233-287.

Mishina, M. (1983), Gravity survey in and around volcanoes Nyamuragira and Nyiragongo, in Volcanoes Nyiragongo and Nyamuragira: Geophysical Aspects, edited by H. Hamaguchi, pp. 69-74, Tohoku Univ., Sendai, Japan.

Montgomery-Brown, E. K., P. Segall, and A. Miklius (2009), Kilauea slow slip events: Identification, source inversions, and relation to seismicity, J. Geophys. Res., 114, B00A03, doi:10.1029/2008JB006074.

Nishimura, T., S. Ozawa, M. Murakami, T. Sagiya, T. Tada, M. Kaidzu, and M. Ukawa (2001), Crustal deformation caused by magma migration in the northern Izu Islands, Japan, Geophys. Res. Lett., 28(19), 3745-3748, doi:10.1029/2001GL013051.

Okada, Y. (1985), Surface deformation due to a shear and tensile faults in a half-space, Bull. Seismol. Soc. Am., 75(4), 1135-1154.

Pallister, J., et al. (2010), Broad accommodation of rift-related extension recorded by dyke intrusion in Saudi Arabia, Nat. Geosci., 3, 705-712, doi:10.1038/ngeo966.

Parsons, T., Y. Ogata, J. Zhuang, and E. L. Geist (2012), Evaluation of static stress change forecasting with prospective and blind test, Geophys. J. Int., 188(3), 1425-1440, doi:10.1111/j.1365-246X.2011.05343.x.

Platz, T., S. F. Foley, and L. Andre (2004), Low-pressure fractionation of the Nyiragongo volcanic rocks, Virunga Province, D. R. Congo, J. Volcanol. Geotherm. Res., 136, 269-295, doi:10.1016/j.jvolgeores.2004.05.020

Poland, M. (2006), InSAR captures rifting and volcanism in East Africa, Alaska Satell. Facil. News Notes, 3, 1, 3

Rivalta, E., and T. Dahm (2005), Buoyancy-driven fracture ascent; experiments in layered gelatine, J. Volcanol. Geotherm. Res., 144, 273-285, doi:10.1016/j.jvolgeores.2004.11.030.

Rivalta, E., and T. Dahm (2006), Acceleration of buoyancy-driven fractures and magmatic dikes beneath the free surface, Geophys. J. Int., 166(3), 1424-1439, doi:10.1111/j.1365-246X.2006.02962.x.

Rivalta, E., and P. Segall (2008), Magma compressibility and the missing source for some dike intrusions, Geophys. Res. Lett., 35, L04306, doi:10.1029/2007GL032521.

Rosen, P. A., S. Hensley, G. Peltzer, and M. Simons (2004), Updated repeat orbit interferometry package released, Eos Trans. $A G U, 85(5), 47$, doi:10.1029/2004EO050004.

Rubin, A. M. (1990), A comparison of rift-zone tectonics in Iceland and Hawaii, Bull. Volcanol., 52, 302-319, doi:10.1007/BF00304101.

Rubin, A. M. (1992), Dike-induced faulting and graben subsidence in volcanic rift zones, J. Geophys. Res., 97(B2), 1839-1858, doi:10.1029/ 91JB02170

Rubin, A. M. (1995), Propagation of magma-filled cracks, Annu. Rev. Earth Planet. Sci., 23, 287-336, doi:10.1146/annurev.ea.23.050195.001443.
Rubin, A. M., D. Gillard, and J.-L. Got (1998), A reinterpretation of seismicity associated with the January 1983 dike intrusions a Kilauea Volcano, Hawaii, J. Geophys. Res., 103(B5), 10,003-10,015, doi:10.1029/ 97JB03513.

Sambridge, M. (1999a), Geophysical inversion with a neighbourhood algorithm - I. Searching a parameter space, Geophys. J. Int., 138, 479-494, doi:10.1046/j.1365-246X.1999.00876.x.

Sambridge, M. (1999b), Geophysical inversion with a neighbourhood algorithm - II. Appraising the ensemble, Geophys. J. Int., 138, 727-746, doi:10.1046/j.1365-246x.1999.00900.x.

Schmid, M., M. Halbwachs, B. Wehrli, and A. Wuest (2005), Weak mixing in Lake Kivu: New insight indicate increasing risk of uncontrolled gas eruption, Geochem. Geophys. Geosyst., 6, Q07009, doi:10.1029/ 2004GC000892.

Schmid, M., M. Busbridge, and A. Wüest (2010), Double diffusive convection in Lake Kivu, Limnol. Oceanogr., 55(1), 225-238, doi:10.4319/ lo.2010.55.1.0225.

Shuler, A., and G. Ekström (2009), Anomalous earthquakes associated with Nyiragongo volcano: Observations and potential mechanisms, J. Volcanol. Geotherm. Res., 181, 219-230, doi:10.1016/j.jvolgeores.2009.01.011.

Smets, B., C. Wauthier, and N. d'Oreye (2010a), A new map of the lava flow field of Nyamulagira (D.R. Congo) from satellite imagery, J. Afr. Earth Sci., 58, 778-786.

Smets, B., M. Kervyn, F. Kervyn, N. d'Oreye, and C. Wauthier (2010b), New insights into eruptive activity and lava flow hazard at Nyamulagira volcano, D.R.C., from a new GIS-based lava flow map, Abstract V11C-2288 presented at 2010 Fall Meeting, AGU, San Francisco, Calif., 13-17 Dec.

Stamps, D. S., E. Calais, E. Saria, C. Hartnady, J.-M. Nocquet, C. J. Ebinger, and R. Fernandes (2008), A kinematic model for the East African Rift, Geophys. Res. Lett., 35, L05304, doi:10.1029/2007GL032781.

Stein, R. S., G. C. P. King, and J. Lin (1992), change in failure stress on the southern San Andreas fault system caused by the 1992 magnitude $=7.4$ Landers earthquake, Science, 258, 1328-1332.

Sun, J., K. J. M. Johnson, Z. Cao, Z. Shen, R. Burgmann, and X. Xu (2011), Mechanical constraints on inversion of coseismic geodetic data for fault slip and geometry: Example from InSAR observation of the October 2008 Mw Dangxiong-Yangyi (Tibet) earthquake, J. Geophys. Res., 116 B01406, doi:10.1029/2010JB007849.

Tanaka, K. (1983), Seismicity and focal mechanism of the volcanic earthquakes in the Virunga Volcanic region, in Volcanoes Nyiragongo and Nyamuragira: Geophysical Aspects, edited by H. Hamaguchi, pp. 19-28, Tohoku Univ., Sendai, Japan.

Tazieff, H. (1977), An exceptional eruption: Mt. Nyiragongo, January 10th, 1977, Bull. Volcanol., 40(3), 189-200, doi:10.1007/BF02596999.

Tedesco, D., O. Vaselli, P. Papale, S. A. Carn, M. Voltaggio, G. M. Sawyer, J. Durieux, M. Kasereka, and F. Tassi (2007), January 2002 volcanotectonic eruption of Nyiragongo Volcano, Democratic Republic of Congo, J. Geophys. Res., 112, B09202, doi:10.1029/2006JB004762.

Townend, J., and M. D. Zoback (2000), How faulting keeps the crust strong, Geology, 28(5), 399-402, doi:10.1130/0091-7613(2000)28<399: HFKTCS $>2.0 . \mathrm{CO} ; 2$.

Traversa, P., V. Pinel, and J. R. Grasso (2010), A constant influx model for dike propagation: Implications for magma reservoir dynamics, J. Geophys. Res., 115, B01201, doi:10.1029/2009JB006559.

Villeneuve M. (1980), La structure du Rift Africain dans la Région du Lac Kivu 680(Zaïre oriental), Bull. Volcanol., 43(3), 541-551, doi:10.1007/ BF02597691.

Wadge, G., and L. Burt (2011), Stress field control of eruption dynamics at a rift volcano: Nyamuragira, D. R. Congo, J. Volcanol. Geotherm. Res. 207, 1-15, doi:10.1016/j.jvolgeores.2011.06.012.

Wauthier, C. (2007), Modélisation des déplacements InSAR survenus au Nyiragongo en janvier 2002, Mém. de Master, vol. 2, Magmas et Volcans, 55 pp., Univ. Blaise Pascal, Clermont-Ferrand, France.

Wauthier, C., et al. (2009) L-band and c-band InSAR studies of African volcanic areas, in 2009 IEEE International Geoscience and Remote Sensing Symposium. IGARSS 2009, vol. II, pp. 210-213, IEEE, Washington, D. C., doi:10.1109/IGARSS.2009.5418043.

Wong, H.-K., and R. P. Von Herzen (1974), A geophysical study of Lake Kivu, East Africa, Geophys. J. R. Astron. Soc., 37, 371-389, doi:10.1111/j.1365-246X.1974.tb04091.x.

Wright, T. J., B. E. Parsons, and Z. Lu (2004), Towards mapping surface deformation in three dimensions using InSAR, Geophys. Res. Lett., 31, L01607, doi:10.1029/2003GL018827.

Wright, T. J., C. Ebinger, J. Biggs, A. Ayele, G. Yirgu, D. Keir, and A. Stork (2006), Magma-maintained rift segmentation at continental rupture in the 2005 Afar dyking episode, Nature, 442(7100), 291-294, do1:10.1038/nature04978. 
Yun, S., P. Segall, and H. Zebker (2006), Constraints on magma chamber geometry at Sierra Negra Volcano, Galápagos Islands, based on InSAR observations, J. Volcanol. Geotherm. Res., 150, 232-243, doi:10.1016/j. jvolgeores.2005.07.009

Zana, N., and H. Hamaguchi (1978), Some characteristics of aftershocks sequences in the western Rift Valley of Africa, Tokohu Geophys J., $25(2), 55-72$.
Zeller, S. S., and D. D. Pollard (1992), Boundary conditions for rock fracture analysis using the boundary element method, J. Geophys. Res., 97(B2), 1991-1997, doi:10.1029/91JB02254.

Zucca, J. J., D. P. Hill, and R. L. Kovach (1982), Crustal structure of Mauna Loa volcano, Hawaii, from seismic refraction and gravity data, Bull. Seismol. Soc. Am., 72, 1535-1550. 